\title{
MECHANISM OF PARATHYROID HORMONE-MEDIATED SUPPRESSION OF CALCIFICATION MARKERS IN HUMAN INTERVERTEBRAL DISC CELLS
}

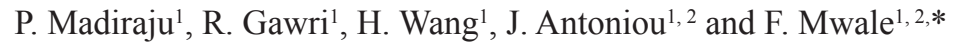 \\ ${ }^{1}$ SMBD-Jewish General Hospital, Lady Davis Institute for Medical Research, Montreal, QC, Canada. \\ ${ }^{2}$ Division of Orthopaedic Surgery, McGill University, Montreal, QC, Canada.
}

\begin{abstract}
In degenerative intervertebral discs (IVD), type $\mathrm{X}$ collagen (COL X) expression (associated with hypertrophic differentiation) and calcification has been demonstrated. Suppression of COL X expression and calcification during disc degeneration can be therapeutic. In the present study we investigated the potential of human parathyroid hormone 1-34 (PTH) in suppressing indicators of calcification potential (alkaline phosphatase (ALP), $\mathrm{Ca}^{2+}$, inorganic phosphate (Pi)), and COL X expression. Further, we sought to elucidate the mechanism of PTH action in annulus fibrosus (AF) and nucleus pulposus (NP) cells from human lumbar IVDs with moderate to advanced degeneration. Mitogen activated protein kinase (MAPK) signalling and alterations in the markers of calcification potential were analysed. PTH increased type II collagen (COL II) expression in AF ( $200 \%)$ and NP cells $(\sim 163 \%)$ and decreased COL X levels both in AF and NP cells ( $\sim 75 \%)$. These changes in the expression of collagens were preceded by MAPK phosphorylation, which was increased in both AF and NP cells by PTH after 30 min. MAPK signalling inhibitor U0126 and protein kinase-A inhibitor H-89 DCH attenuated PTH stimulated COL II expression in both cell types. PTH decreased ALP activity and increased $\mathrm{Ca}^{2+}$ release only in NP cells. The present study demonstrates that PTH can potentially retard IVD degeneration by stimulating matrix synthesis and suppressing markers of calcification potential in degenerated disc cells via both MAPK and PKA signalling pathways. Inhibition of further mineral deposition may therefore be a viable therapeutic option for improving the status of degenerating discs.
\end{abstract}

Keywords: Parathyroid hormone; intervertebral disc degeneration; disc calcification; type X collagen; type II collagen; gene expression; mitogen-activated protein kinase.

\footnotetext{
*Address for correspondence:

Fackson Mwale

Lady Davis Institute for Medical Research, Room 602

3755 Cote Ste-Catherine Road, Montreal, QC, H3T 1E2

Canada
}

Telephone Number: (514) 340-8222 ext 2948

FAX Number: (514) 340-7502,

E-mail: fmwale@ldi.jgh.mcgill.ca

\section{Introduction}

Back pain is closely associated with intervertebral disc (IVD) degeneration (Bogduk, 1991; Freemont, 2009). It afflicts nearly $85 \%$ of the population during their lifetime (Loreto et al., 2011). Vertebrae are joined by the IVDs and their degeneration is closely linked to ageing (Adams and Roughley, 2006). IVD degeneration affects the mechanical function and strength of the spine even though the aetiology of this degeneration is not well defined (Freemont, 2009). IVDs are composite structures devoid of vasculature, with an outer collagen rich annulus fibrosis (AF) surrounding the proteoglycan-rich inner nucleus pulposus (NP) and cartilaginous endplates (Hayes et al., 2001). The AF is composed of fibrochondrocyte-like cells of mesenchymal origin, while the NP is populated by chondrocyte-like cells, which are derived from the notochord (Oegema, 1993; Buckwalter, 1995). During ageing and disc degeneration human disc cells go through several biochemical changes, including increased type I collagen (COL I) and decreased type II collagen (COL II) in NP leading to fibrosis of the NP. Also there is an increased expression of type X collagen (COL X) (Antoniou et al., 1996; Boos et al., 1997), which normally exists only in foetal NP, cartilaginous endplate (CEP) and severely degenerated IVDs.

Biological changes that occur during and in response to disc degeneration include increased cell death followed by increased proliferation (Boos et al., 2002). Because of this, although there is an increased cell density (Gruber and Hanley, 1998) the number of viable cells is decreased with ageing and degeneration (Bibby et al., 2002). Interstitial and pericellular calcification leads to the death of viable cells surrounded by extracellular matrix in NP, reducing the turnover of these cells and thus impairing nucleus viability (Loreto et al., 2011).

Parathyroid hormone (PTH), a polypeptide secreted from parathyroid glands, is a well-known mediator of bone remodelling and regulator of calcium homeostasis (Swarthout et al., 2002). PTH has catabolic effects, by which it causes bone resorption by indirect activation of osteoclasts and also anabolic effects, which lead to bone formation (Dempster et al., 1993). The catabolic effects of PTH are associated with its long-term exposure, whereas its intermittent use exerts anabolic effects on skeletal tissue (Dobnig and Turner, 1995; Schiller et al., 1999). The action of PTH is also concentration dependent, showing catabolic effects at higher concentrations and anabolic effects at lower concentrations (Swarthout et al., 2002). PTH action on its target cells is initiated by binding to its receptor, PTH1R, which is a G-protein-coupled receptor (GPCR) 
(Swarthout et al., 2002; Kawane et al., 2003). Activation of PTH1R by PTH leads to the formation of cyclic AMP via the Gas-mediated stimulation of adenylate cyclase (Swarthout et al., 2002; Kawane et al., 2003). This leads to the activation of protein kinase $\mathrm{A}$ and its downstream signalling. PTH is also known to activate phospholipase $\mathrm{C} \beta$ via $\mathrm{G} \alpha \mathrm{q}$, leading to the formation of diacylglycerol and 1,4,5-inositol triphosphate (IP3) with the subsequent activation of protein kinase C (Civitelli et al., 1988; Babich et al., 1991) and increased intracellular free $\mathrm{Ca}^{2+}$ (Reid et al., 1987). PTH can also elevate intracellular $\mathrm{Ca}^{2+}$ levels by stimulating the influx of extracellular $\mathrm{Ca}^{2+}$ (Swarthout et al., 2002). It is known that PTH, at low concentrations, stimulates mitogen-activated protein kinase (MAPK) and cell proliferation in a protein kinase $\mathrm{C}$-dependent manner in osteoblasts (Swarthout et al., 2002). Besides affecting $\mathrm{Ca}^{2+}$ levels, PTH has also been shown to decrease the expression of alkaline phosphatase (ALP) in osteoblasts (Partridge et al., 1994). The presence of calcium deposits and COL $\mathrm{X}$ and also the levels of the indicators of calcification potential (ALP, $\mathrm{Ca}^{2+}$ ions and inorganic phosphate (Pi)) were consistently higher in the degenerative and scoliotic discs (Hristova et al., 2011). We previously showed that in mesenchymal stem cells (MSCs) from osteoarthritis (OA) patients, PTH is able to inhibit the expression of COL X while promoting the expression of COL II, thereby preventing endochondral ossification (Mwale et al., 2010). Inasmuch as PTH exhibits both anabolic and catabolic effects on bone cells, it is important to examine the effects of this hormone on IVD cells and to ascertain if PTH plays a role in the repair of disc degeneration.

In the present study, we investigated the potential of the N-terminal fragment 1-34 of human parathyroid hormone (hereafter referred to as PTH) in suppressing indicators of calcification potential and analysed the possible mechanisms related to its effect in human IVD cells. The results suggest that PTH is able to stimulate disc repair in the degenerative disc by up-regulating COL II and down-regulating COL X via MAPK signalling as well as suppressing markers of calcification potential in human IVD cells.

\section{Materials and methods}

All the experiments in the present study involving human tissue samples were performed in accordance with the principles of Helsinki using Institutional Review Board (IRB)-approved protocols.

In this study we employed the disc cells (AF and NP) isolated from human IVDs with grade III or grade IV of degeneration. Thus, the data presented here represent a combined average of results obtained from 3-6 independent experiments (see figure legends) from both the IVD cells and the cells isolated from different donors and different discs from the each donor were not pooled.

The concentration of PTH was chosen at $100 \mathrm{nM}$ in the present study as the affinity (binding constant) of PTH to the PTH receptor is in the range of $2-3 \mathrm{nM}$, reaching saturation only at about $100 \mathrm{nM}$ (Vilardaga et al., 2003). Production of cAMP by PTH stimulation also was shown to follow similar PTH concentration kinetics (Vilardaga et al., 2003).

\section{Isolation and culture of human IVD cells}

Human lumbar IVDs from donors without spinal pathology were obtained through organ donations via Transplant Quebec (Montreal, QC, Canada) within $24 \mathrm{~h}$ after death. A total of 5 spines (4 discs each) from donors ranging in age from 35-55 y were used for cell isolation. The discs were graded morphologically, using the Thompson grading system for disc degeneration (Thompson et al., 1990), and were all classified from grade I to V. NP and AF tissues from the IVDs of grade III and IV, which indicate moderate to advanced disc degeneration, were digested and the corresponding NP and AF primary cells were isolated as previously described (Chelberg et al., 1995). Briefly, the $\mathrm{NP}$ and AF regions of the disc were minced into small pieces and were processed separately. The tissues were digested initially in culture medium (Ham F-12 medium containing $5 \%$ foetal bovine serum, $150 \mathrm{ng} / \mathrm{mL}$ gentamicin) supplemented with $0.2 \%$ pronase (Sigma-Aldrich, St. Louis, MO, USA) and $0.004 \%$ deoxyribonuclease II (Sigma-Aldrich) for $60 \mathrm{~min}$ at $37^{\circ} \mathrm{C}$, with gentle agitation, followed by overnight digestion in fresh culture medium supplemented with bacterial collagenase type II (SigmaAldrich) at $0.01 \%$ for the NP and $0.04 \%$ for the AF. Cells were cultured in Dulbecco's Modified Eagle's Medium (DMEM) (4.5 g/L glucose) supplemented with $10 \%$ foetal bovine serum (FBS), $100 \mathrm{U} / \mathrm{mL}$ penicillin and $100 \mu \mathrm{g} /$ $\mathrm{mL}$ streptomycin to $80-90 \%$ confluence at $37{ }^{\circ} \mathrm{C}, 5 \%$ $\mathrm{CO}_{2}$. The cells were passaged with $0.25 \%$ Trypsin-EDTA (Gibco, Burlington, ON, Canada) and only passages 2 and 3 were used. Gene expression of aggrecan, collagens type I and II after passaging supported the phenotypic stability of these cells in culture (Fig. 1). Confluent cells were starved overnight by incubation in DMEM without FBS at $37{ }^{\circ} \mathrm{C}$, to eliminate the interference of growth factors present in the serum. Then the cells were treated with $100 \mathrm{nM}$ human parathyroid hormone N-terminal peptide 1-34 (PTH) (Sigma-Aldrich) for $30 \mathrm{~min}$ to $48 \mathrm{~h}$. Human PTH (1-34) was reported to have the same activity as that of the native peptide of 84 amino acids (Caporale et al., 2012). Control cultures were supplemented only with vehicle $\left(\mathrm{H}_{2} \mathrm{O}\right.$ or dimethyl sulphoxide (DMSO)). For the studies with inhibitors, disc cells were treated with $10 \mu \mathrm{M}$ MEK inhibitor, 1,4-diamino-2, 3-dicyano-1,4-bis [2-aminophenylthio] butadiene (U0126, Sigma-Aldrich) or with $20 \mu \mathrm{M}$ cAMP dependent protein kinase (protein kinase A) inhibitor (H-89 dihydrochloride hydrate) for 30 min prior to stimulation with PTH.

\section{Isolation and extraction of protein from human IVD tissues}

Human lumbar IVDs were excised from spines of 3 different donors aged 24, 54 and $68 \mathrm{y}$. The discs were graded and AF and NP tissues were isolated as described in the section entitled "Isolation and culture of human IVD cells". Protein was extracted and solubilised from $10 \mathrm{mg}$ of homogenised tissue, by mechanical shear and sonication in $1 \mathrm{~mL}$ of Sigma's RIPA Buffer (150 mM NaCl, $1.0 \%$ IGEPAL $^{\circledR}$ CA-630, $0.5 \%$ sodium deoxycholate, $0.1 \%$ 
a)

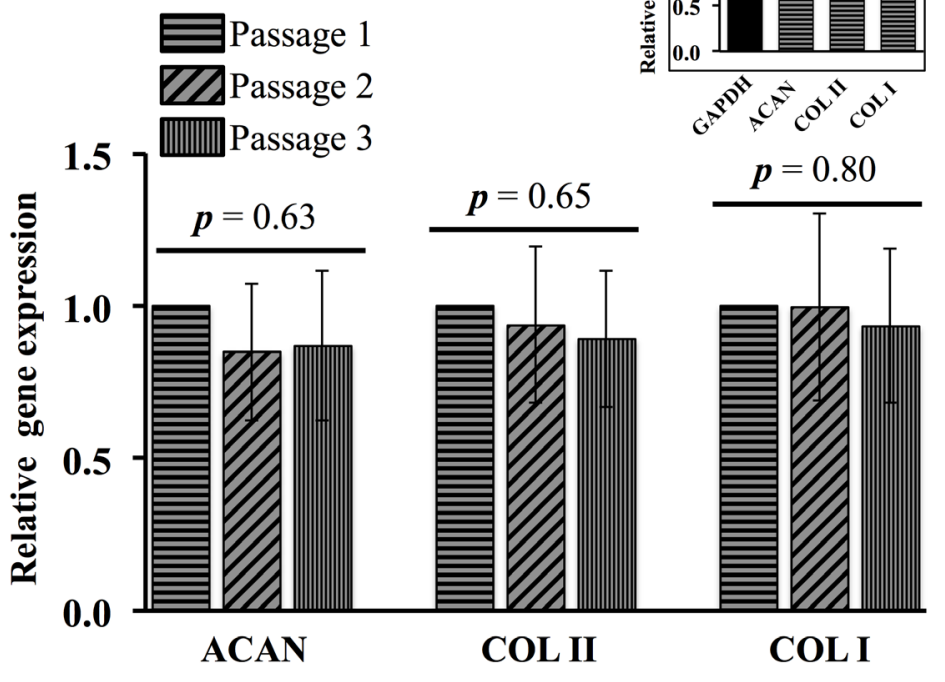

b)

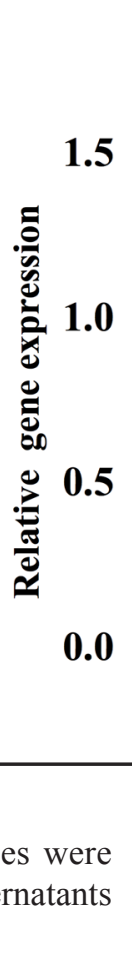

centrifuged at 2,000 g for $10 \mathrm{~min}$ and the supernatants were used for SDS PAGE.

\section{Western blotting}

At the end of incubations with PTH, cells were washed twice with $1 \times$ phosphate-based saline (PBS) and lysed in lysis buffer (10 mM HEPES, $50 \mathrm{mM} \mathrm{Na}_{4} \mathrm{P}_{2} \mathrm{O}_{7}, 50 \mathrm{mM} \mathrm{NaF}$, $50 \mathrm{mM} \mathrm{NaCl}, 5 \mathrm{mM}$ EDTA, $5 \mathrm{mM}$ EGTA, $2 \mathrm{mM} \mathrm{Na}_{3} \mathrm{VO}_{4}$, $1 \%$ Triton X-100, $1 \%$ protease inhibitor cocktail (Roche Diagnostics, Laval, QC, Canada), $\mathrm{pH}$ adjusted to 7.4). Total protein content in the cell extracts was determined by the Bradford assay and equal amounts of protein from each sample were resolved on $10 \%$ acrylamide gel and after SDS-PAGE, the separated proteins were transferred to nitrocellulose membranes by semi-dry electrophoretic transfer using Trans-Blot ${ }^{\circledR}$ SD Semi-Dry Electrophoretic
AF cells
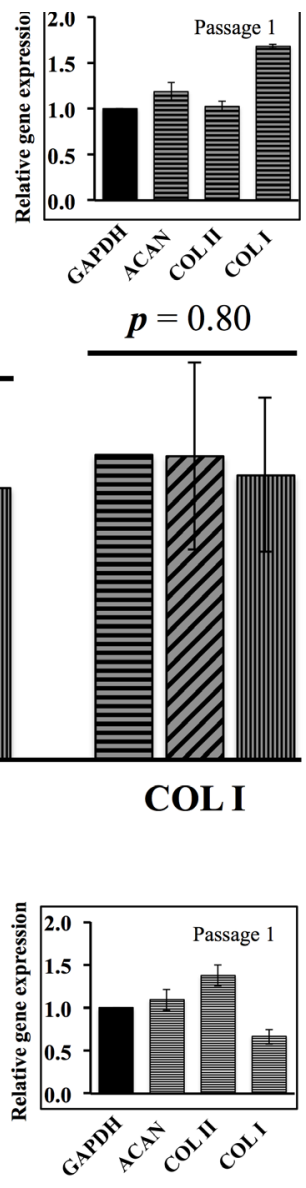

Passage 2

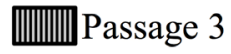
$\mathrm{c}^{\text {s. }}$ $\boldsymbol{p}=0.94$

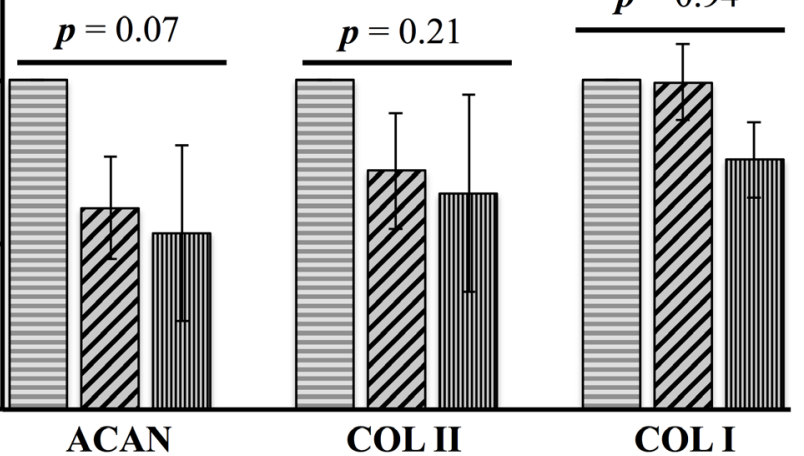

Transfer Cell (Bio-Rad, Mississauga, ON, Canada) or using liquid transfer apparatus (Bio-Rad). After transfer, the membranes were washed twice in Tris-buffered saline/ Tween 20 (TBST) and then incubated in TBST containing $5 \%$ skim milk at room temperature for $1 \mathrm{~h}$. The membranes were then incubated overnight at $4{ }^{\circ} \mathrm{C}$ with specific antibodies against target proteins. Protein expression was analysed by immunoblotting using specific antibodies to COL II (Abcam, Cambridge, MA, USA; 1:1000), or COL $\mathrm{X}$ (Sigma-Aldrich; 1:1000). As SOX-9 transcription factor is known to control the expression of COL-II (Lefebvre et al., 2001), we examined if PTH treatment of IVD cells led to the activation of SOX-9 by its phosphorylation. The expression and phosphorylation of SOX-9 (Cell Signaling, Danvers, MA, USA; pSOX-9 and SOX-9; 1:1000) and MAPKs (pErk1/2 and Erk1/2; 1:5000, pJNK and JNK; $1: 1000$, p-p38; 1:500 and p38; 1:1000) were assessed 
Table 1. Primer sequences.

\begin{tabular}{|l|l|l|}
\hline Gene & Sequence & Size (bp) \\
\hline COL10A1 & $\begin{array}{l}\text { Forward (1670-1690): AAT GCC TGT GTC TGC TTT TAC } \\
\text { Reverse (1779-1799): ACA AGT AAA GAT TCC AGT CCT }\end{array}$ & 130 \\
\hline COL2A1 & $\begin{array}{l}\text { Forward (459-478): ATT TCA AGG CAA TCC TGG TG } \\
\text { Reverse (657-676): GGC CTG GAT AAC CTC TGT GA }\end{array}$ & 218 \\
\hline COL1A1 & $\begin{array}{l}\text { Forward: GAG AGC ATG ACC GAT GGA TT } \\
\text { Reverse: CCT TCT TGA GGT TGC CAG TC }\end{array}$ & 178 \\
\hline ACAN & $\begin{array}{l}\text { Forward: TGA GTC CTC AAG CCT CCT GT } \\
\text { Reverse: CCT CTG TCT CCT TGC AGG TC }\end{array}$ & 185 \\
\hline GAPDH & $\begin{array}{l}\text { Forward (113-133): TGA AGG TCG GAG TCA ACG GAT } \\
\text { Reverse (273-293): TTC TCA GCC TTG ACG GTG CCA }\end{array}$ & 181 \\
\hline
\end{tabular}

by using specific antibodies (Cell Signaling). PTH1R antibody (3D 1.1) was from Novus Biologicals (Oakville, ON, Canada; 1:1000). Glyceraldehyde-3-phosphate dyhydrogenase (GAPDH) (Sigma-Aldrich; 1:10000) was used to normalise the results. Chemiluminescent reagents (Amersham $^{\mathrm{TM}}$ ECL Western Blotting Detection Reagents (Amersham, UK)) were used to visualise the protein bands on the immunoblots. Western blot photographic films were scanned and pixel intensity was quantified by densitometry using Image J (NIH, Bethesda, MD, USA) software.

ALP activity was measured colourimetrically using the StemTAG kit (Cell Biolabs, San Diego, CA, USA) and $\mathrm{Ca}^{2+}$ release from cells was measured using calcium assay kit (Cayman Chemical, Ann Arbor, MI, USA) according to the kit manufacturer's protocol.

\section{Measurement of COL II and COL X gene expression by real time PCR}

At the end of incubation with PTH total RNA from AF and NP cells was isolated using Trizol reagent (Invitrogen, Burlington, ON, Canada). The resulting RNA pellet was washed with $75 \%$ ethanol, and then centrifuged and air-dried. Then the pellets were suspended in $50 \mu \mathrm{L}$ of diethylpyrocarbonate-treated water and RNA concentration was determined. Reverse transcription was performed using the purified RNA $(1 \mu \mathrm{g})$ by mixing with random primers (final concentration $0.15 \mu \mathrm{g} / \mu \mathrm{L}$ ), dNTP mixture (final concentration $0.5 \mathrm{mmol} / \mathrm{L}$ ) and diethylpyrocarbonatetreated water in a final volume of $12 \mu \mathrm{L}$. After the solution was incubated at $65^{\circ} \mathrm{C}$ for $5 \mathrm{~min}$, it was mixed with first strand buffer, dithiotreitol (DTT), RNaseOUT and Superscript II reverse transcriptase in a final volume of $20 \mu \mathrm{L}$. Then the solution was incubated at $45^{\circ} \mathrm{C}$ for $50 \mathrm{~min}$ and then at $70{ }^{\circ} \mathrm{C}$ for $15 \mathrm{~min}$ to inactivate the reverse transcriptase. For LightCycler real time PCR, a master mix of the following reaction components was prepared with final concentrations: $10 \mu \mathrm{L}$ SYBER PCR master mix (1×) (Qiagen, ON, Canada), $8 \mu \mathrm{L}$ water, $0.5 \mu \mathrm{L}$ forward primer $(0.25 \mu \mathrm{M}), 0.5 \mu \mathrm{L}$ reverse primer $(0.25 \mu \mathrm{M})($ Table 1). To this mix, $1 \mu \mathrm{L}$ of cDNA was added as PCR template.

The reaction conditions included one cycle of $95{ }^{\circ} \mathrm{C}$ for $15 \mathrm{~min}, 45$ cycles of amplification and quantification $\left(94{ }^{\circ} \mathrm{C}\right.$ for $15 \mathrm{~s}, 57^{\circ} \mathrm{C}$ for $30 \mathrm{~s}, 72^{\circ} \mathrm{C}$ for $30 \mathrm{~s}$ ), one cycle of melting curve $\left(65-95{ }^{\circ} \mathrm{C}\right.$ with heating rate of $0.1{ }^{\circ} \mathrm{C}$ per second with a continuous fluorescence measurement), and a final cooling step to $4{ }^{\circ} \mathrm{C}$. The crossing points (CP) were determined by the Light Cycler software 3.3 (Roche Diagnostics) and were measured at constant fluorescence level. Every sample was run in triplicates and the average value was used in the calculation. The relative gene transcription was determined by the following equation and GAPDH was employed as the reference gene:

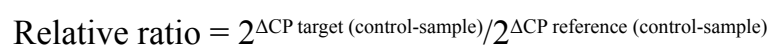

\section{Statistical analyses}

Data are expressed as means \pm standard error (SE) and were analysed by one-way analysis of variance (ANOVA) followed by post-hoc tests (Bonferroni and NewmanKeuls method). A mean difference between groups was considered statistically significant at $p<0.05$.

\section{Results}

\section{PTH differentially regulates type II and type X collagen expression}

PTH increased the expression of COL II protein significantly $(200 \pm 51 \%$ of control; $p<0.05)$ in AF cells after $6 \mathrm{~h}$ of incubation and decreased to statistically nonsignificant levels after $24 \mathrm{~h}$ but was still maintained above control levels. On the other hand, in NP cells COL II protein increased in a time-dependent and sustained manner, from $6 \mathrm{~h}(163 \pm 47 \%$ of control; $p<0.05)$ to $48 \mathrm{~h}(188 \pm 27 \%$ of control; $p<0.01$ ) of incubation (Fig. 2a). Addition of PTH to AF cells increased the expression of COL II mRNA by 1.5 -fold at $6 \mathrm{~h}(p=0.043)$, which remained almost at the same level up to $24 \mathrm{~h}(p=0.063)$. In NP cells, PTH induced COL II mRNA levels by 2.3 -fold at $6 \mathrm{~h}(p=0.012)$ (Fig. 2b).

In AF cells, a significant decrease in expression of COL X was observed only after 6 h $(75 \pm 9 \%$ of control; $p<0.01$ ). After $24 \mathrm{~h}$ and $48 \mathrm{~h}$ there was no significant change in COL X expression. However, in NP cells COL $\mathrm{X}$ expression decreased significantly from $6 \mathrm{~h}(74 \pm 11 \%$ of control; $p<0.01)$ to $48 \mathrm{~h}(29 \pm 8.5 \%$ of control; $p<0.001)$ (Fig. 3a). In AF cells, addition of PTH did not have any significant effect on COL X mRNA levels, which were 
a) AF cells

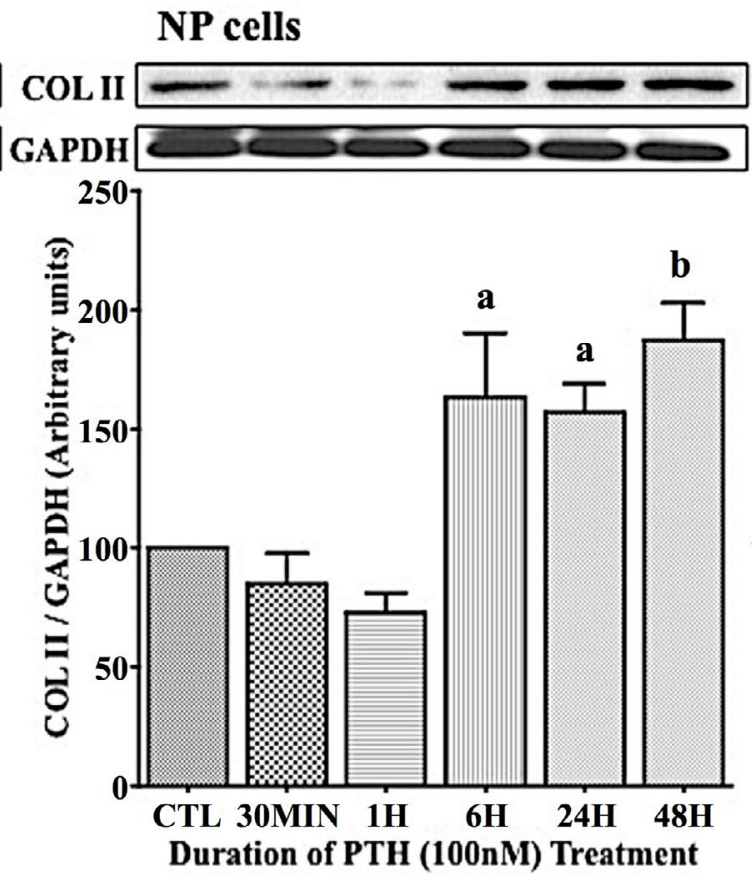

b)
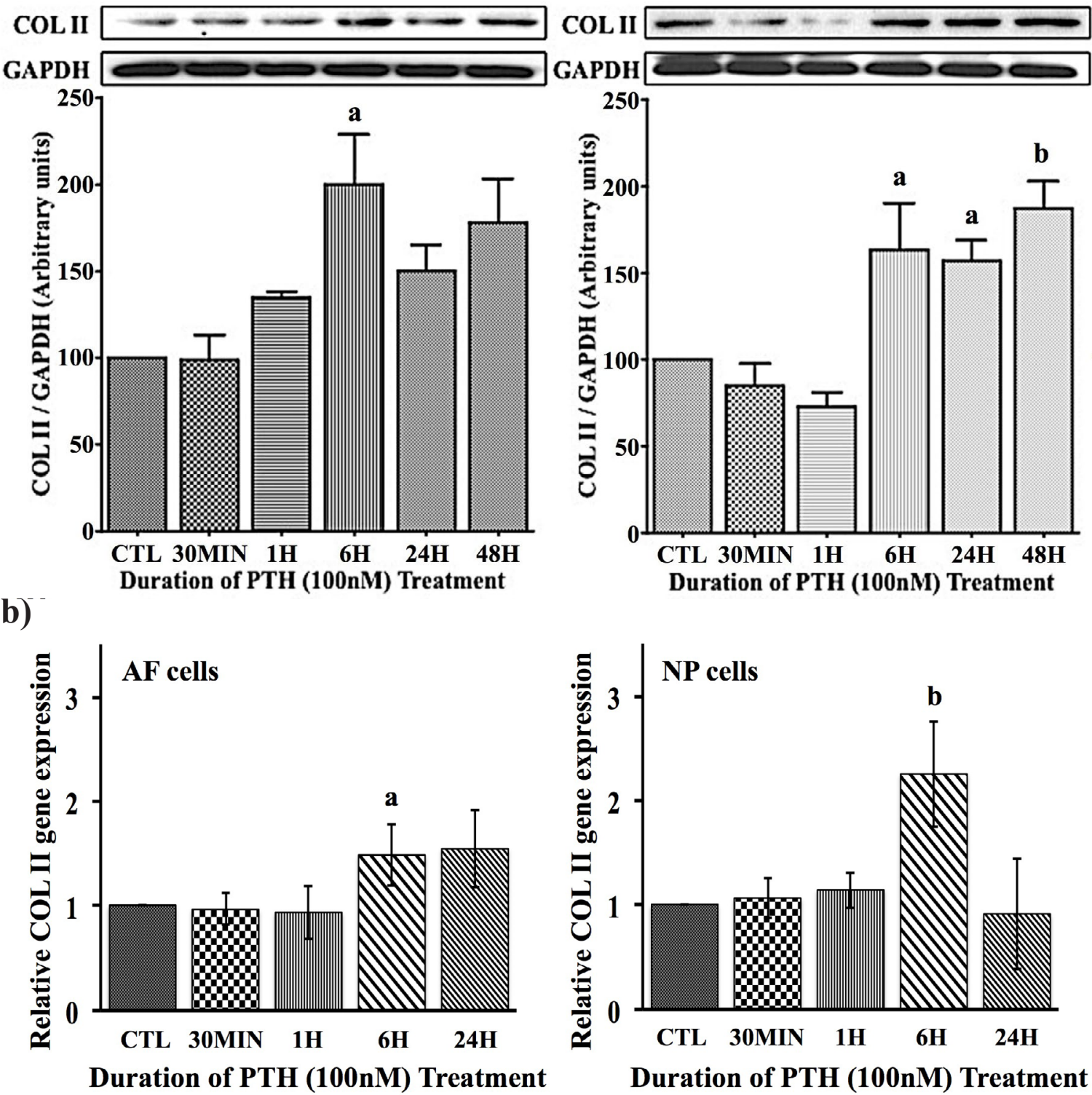

Fig. 2. Effect of human parathyroid hormone 1-34 (PTH) on type II (COL II) collagen protein and gene expression in annulus fibrosus (AF) and nucleus pulposus (NP) cells from human intervertebral disc. AF and NP cells were cultured for up to $48 \mathrm{~h}$ in the absence (CTL) or presence of $100 \mathrm{nM}$ PTH. (a) Equal amounts of proteins from each sample were resolved on $10 \%$ denaturing acrylamide gel and transferred to nitrocellulose membranes. Protein expression was analysed by immunoblotting using specific antibodies. GAPDH was used as a loading control and served to normalise the results. Proteins were quantified by densitometric scanning and blots are shown for 1 representative experiment. Quantitative results depicting the combined data for three separate experiments with cells isolated from spines obtained from three donors are presented as percentage of control (CTL). Results are mean $\pm \mathrm{SE}\left({ }^{\mathrm{a}} p<0.05\right.$; ${ }^{\mathrm{b}} p<0.01 v s$. control). (b)The relative basal gene expression of COL II (COL2A1 gene) in AF and NP cells treated with PTH up to $24 \mathrm{~h}$ was compared to control. Gene expression was measured by real time RT PCR. GAPDH was used as reference gene and the values are mean $\pm \mathrm{SE}\left({ }^{\mathrm{a}} p<0.05 ;{ }^{\mathrm{b}} p<0.01 v s\right.$. control).

reduced significantly in NP cells by 30 min and reached control levels after $24 \mathrm{~h}$ (Fig. 3b).

Effect of PTH on alkaline phosphatase activity

In AF cells, no significant changes in ALP activity were observed by PTH treatment and there was a trend towards an increase at $48 \mathrm{~h}$. In contrast, ALP activity began to decrease in NP cells after $6 \mathrm{~h}$ of PTH treatment and the decrease was significant at $24 \mathrm{~h}(76 \pm 7.7 \%$ of control; $p<0.01)$ and $48 \mathrm{~h}(67 \pm 7.9 \%$ of control; $p<0.001)$ (Fig. $4 a)$.

Effect of PTH on extracellular calcium release We next tested the effect of PTH on the cellular levels of calcium and also on the extracellular release of calcium. Although AF cells showed a tendency for increased calcium release in the media and a concomitant decrease in cellular calcium after $24 \mathrm{~h}$ and $48 \mathrm{~h}$, this was not significant. 
a)
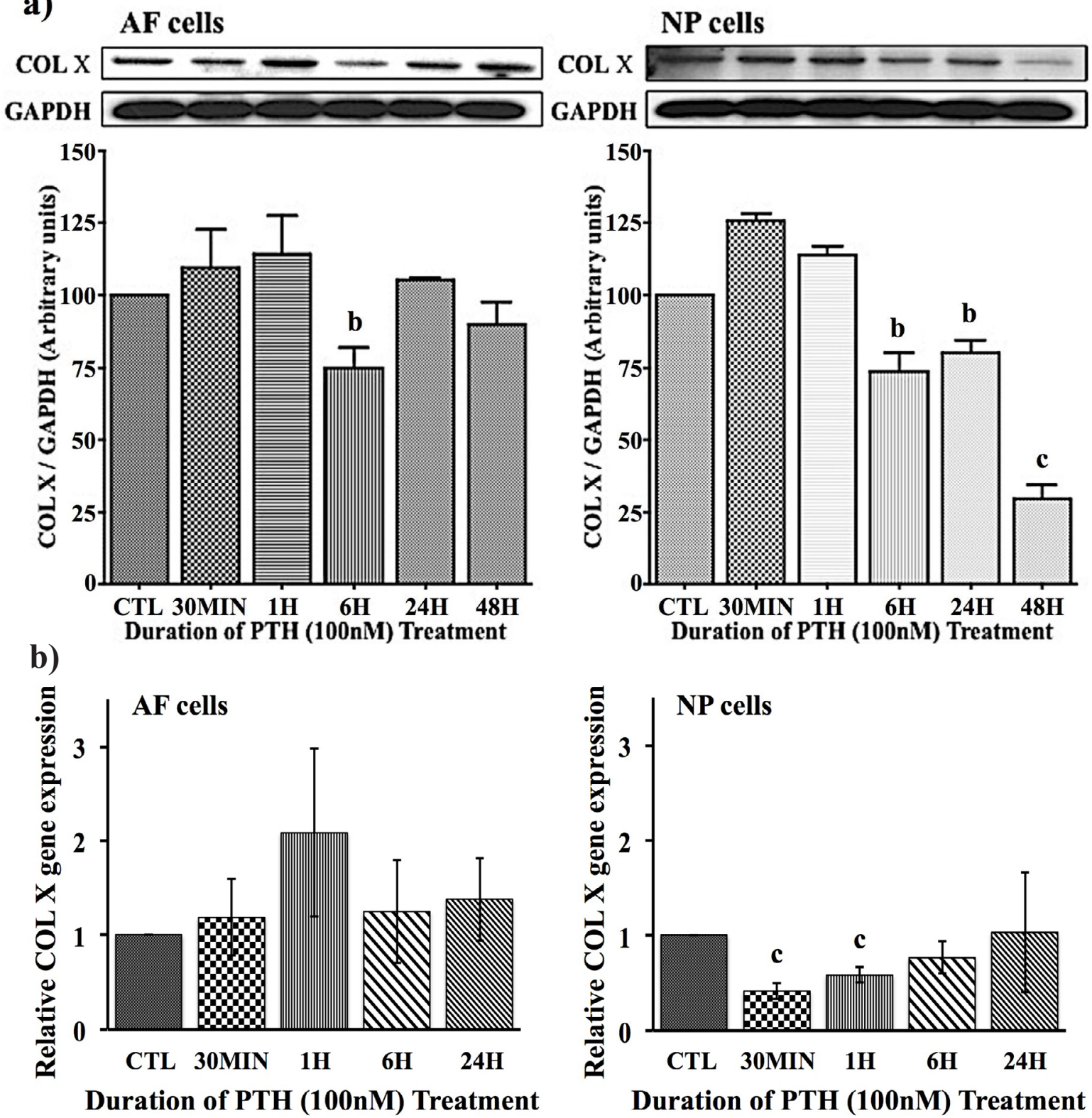

Fig. 3. Effect of human parathyroid hormone 1-34 (PTH) on type X (COL X) collagen protein and gene expression in annulus fibrosus (AF) and nucleus pulposus (NP) cells from human intervertebral disc. AF and NP cells were cultured for up to $48 \mathrm{~h}$ in the absence (CTL) or presence of $100 \mathrm{nM}$ PTH. (a) Equal amounts of proteins from each sample were resolved on $10 \%$ denaturing acrylamide gel and transferred to nitrocellulose membranes. Protein expression was analysed by immunoblotting using specific antibodies. GAPDH was used as a loading control and served to normalise the results. Proteins were quantified by densitometric scanning and blots are shown for 1 representative experiment. Quantitative results depicting the combined data for 3 separate experiments are presented as percentage of control (CTL). Results are mean $\pm \mathrm{SE}\left({ }^{\mathrm{b}} p<0.01 ;{ }^{\mathrm{c}} p<0.001 \mathrm{vs}\right.$. control). (b) The relative basal gene expression of COL X (COL10A1 gene) in AF and NP cells treated with PTH up to $24 \mathrm{~h}$ was compared to control. Gene expression was measured by real time RT PCR. GAPDH was used as reference gene and the values are mean $\pm \mathrm{SE}\left({ }^{\mathrm{c}} p<0.001 v s\right.$. control).

However, PTH caused a significant increase in calcium release in NP cells after $48 \mathrm{~h}(41 \pm 2.9 \%$, of control; $p<0.01$ ), which was accompanied by a corresponding decrease in cellular calcium (Fig. 4b).

Effect of PTH on PTH 1 receptor expression

The results showed the expression of $\mathrm{PTH}$ receptor (PTH1R) in both AF and NP tissues of human IVDs with different grades of degeneration, suggesting that the receptors are present in the AF and NP tissues, in their native state. There appears to be a correlation between the degree of degeneration and receptor expression (Fig. 5a). Furthermore, increased receptor expression is seen with age. Prior exposure to PTH had no statistically significant effect on the PTH1R protein levels in both the cell types. However, there seems to be an increase in the receptor 
a)
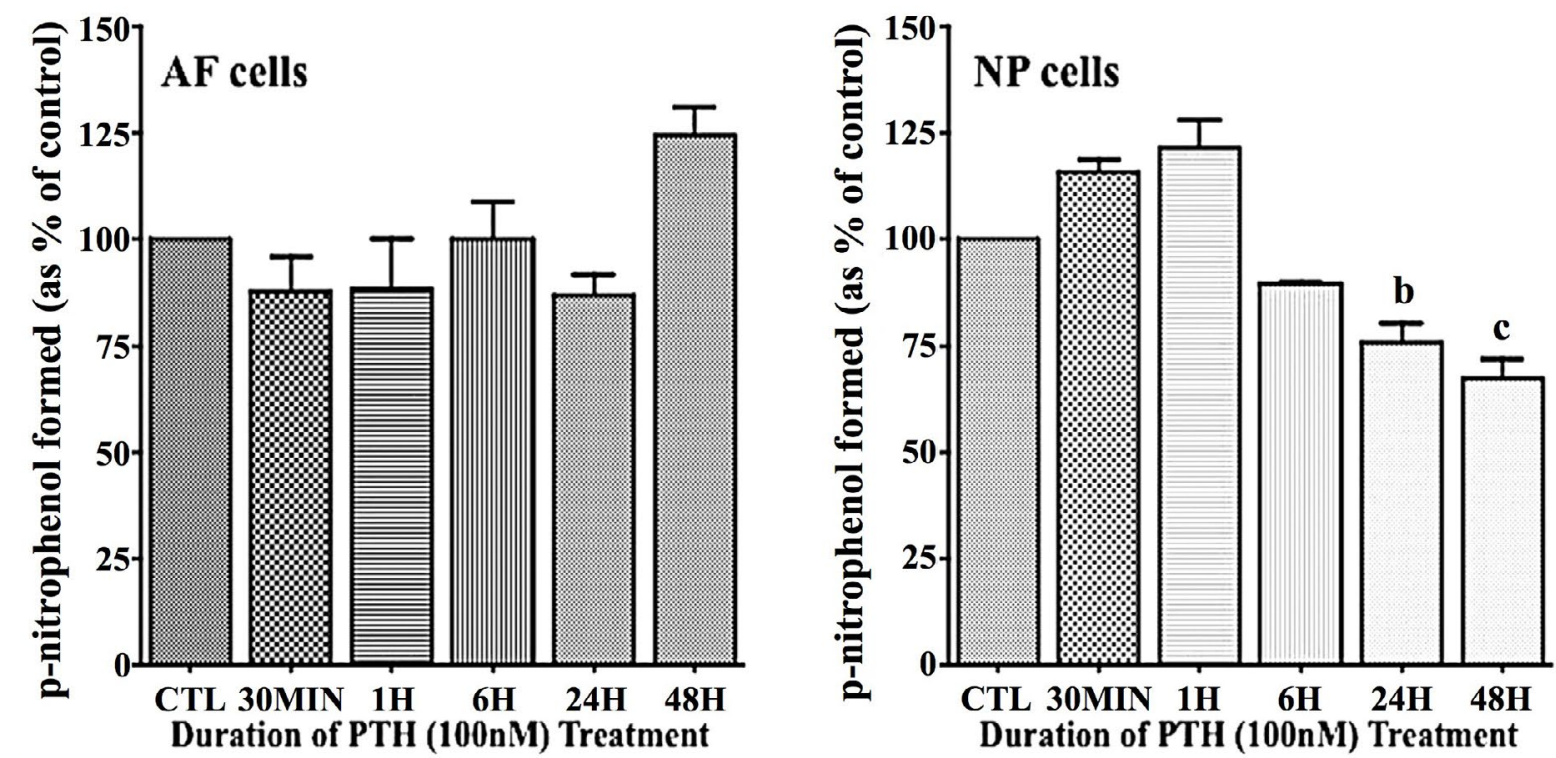

b)
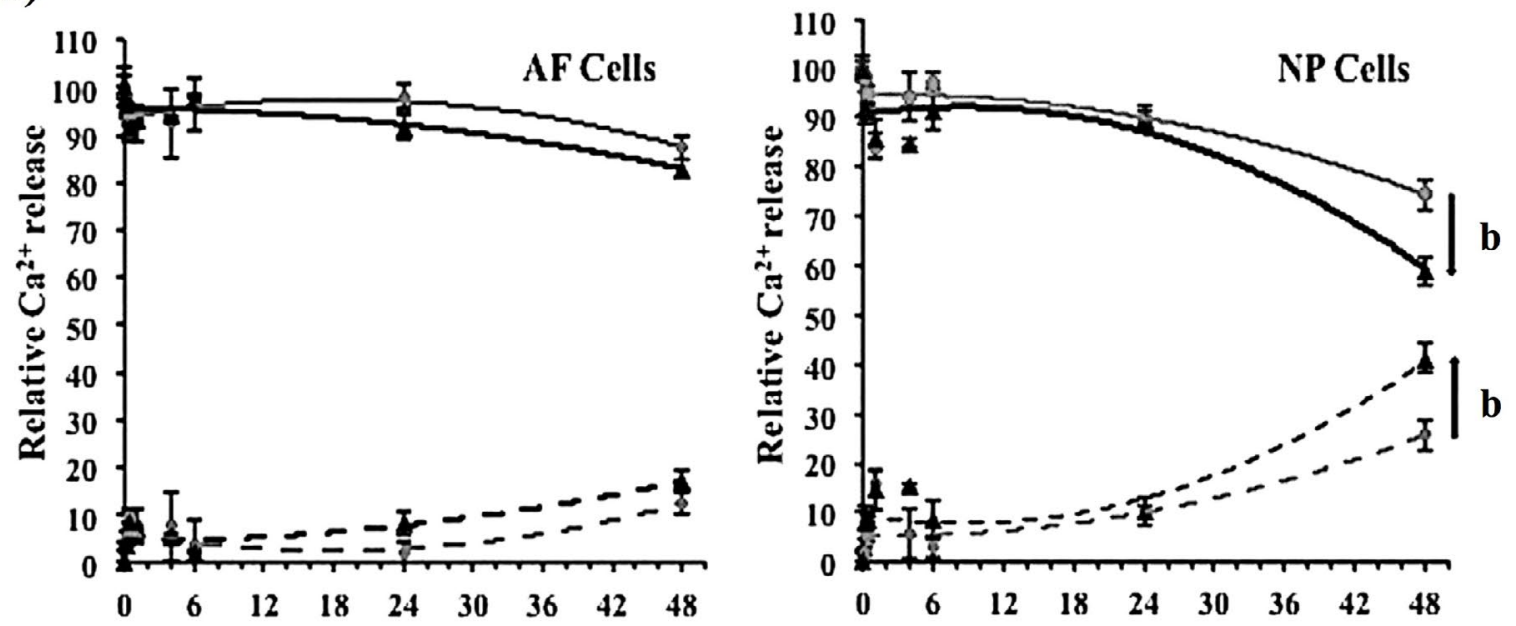

Duration of PTH (100nM) Treatment (H)

Duration of PTH (100nM) Treatment(H)
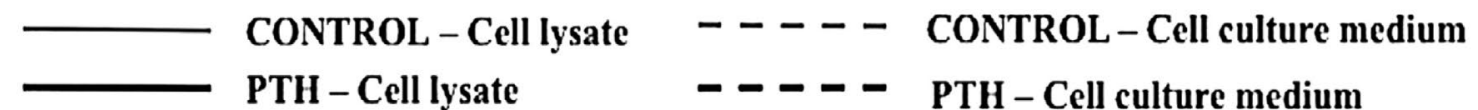

Fig. 4. Effect of human parathyroid hormone 1-34 (PTH) on alkaline phosphatase activity and calcium $\left(\mathrm{Ca}^{2+}\right)$ release in annulus fibrosus (AF) and nucleus pulposus (NP) cells from human intervertebral disc. AF and NP cells were cultured for $48 \mathrm{~h}$, supplemented with either $100 \mathrm{nM}$ PTH or without PTH (CTL). (a) ALP activity (p-nitrophenol $\mathrm{nmol} / \mathrm{mg}$ protein) was measured colourimetrically using the StemTAG kit. (b) $\mathrm{Ca}^{2+}$ concentrations in the cell lysates and in the culture media were measured at different time durations of PTH treatment using a calcium assay kit (see Materials and Methods). Total protein in the samples was used to normalise the values. Results are mean $\pm \operatorname{SE}(n=6$; ${ }^{\mathrm{b}} p<0.01 ;{ }^{\mathrm{c}} p<0.001 v s$. control).

expression after $6 \mathrm{~h}$ in NP cells, which was not evident in the case of AF cells (Fig. 5b).

\section{Effect of PTH on MAPK signalling}

In order to delineate the mechanisms underlying the changes in the expression of collagens, we examined if PTH has any effects on MAPK signalling, which is known to influence collagen expression (Mwale et al., 2010). We first examined the phosphorylation and activation of Erk1/2 and our results showed that exposure of AF and NP cells to PTH cause Erk1/2 activation by phosphorylation within 30 min (Fig. 6a). PTH stimulated phosphorylation of Erk1/2 was sustained up to $6 \mathrm{~h}$ followed by slow decrease, but did not reach basal levels even after $48 \mathrm{~h}$ in both cell types. The effects of PTH on Erk1/2 activation in NP cells were more pronounced, when compared with AF cells. In fact, the activation in NP cells remained significantly higher than the control even after $48 \mathrm{~h}(473 \pm 28 \%$, $p<0.01)$ incubation, whereas in AF cells it reached to non-significant levels by $24 \mathrm{~h}$. The relative extent of Erk $1 / 2$ 
a)

AF tissue

NP tissue

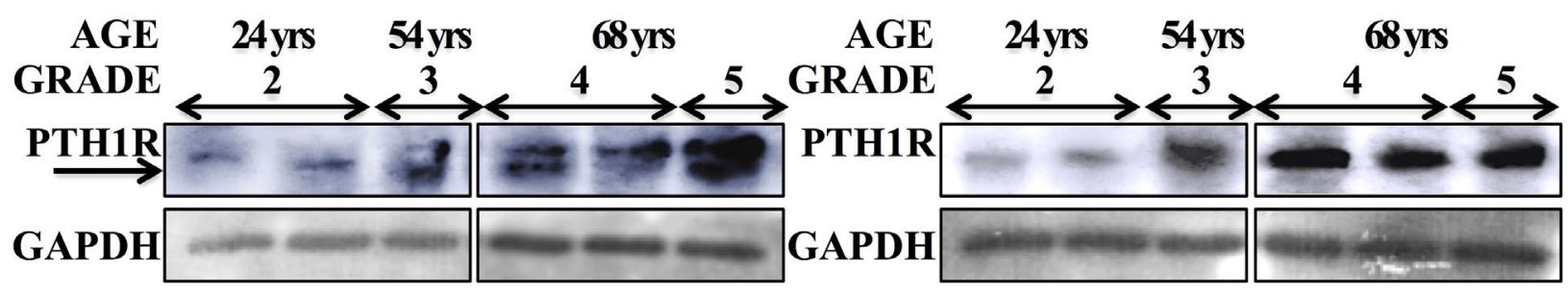

b)

AF cells
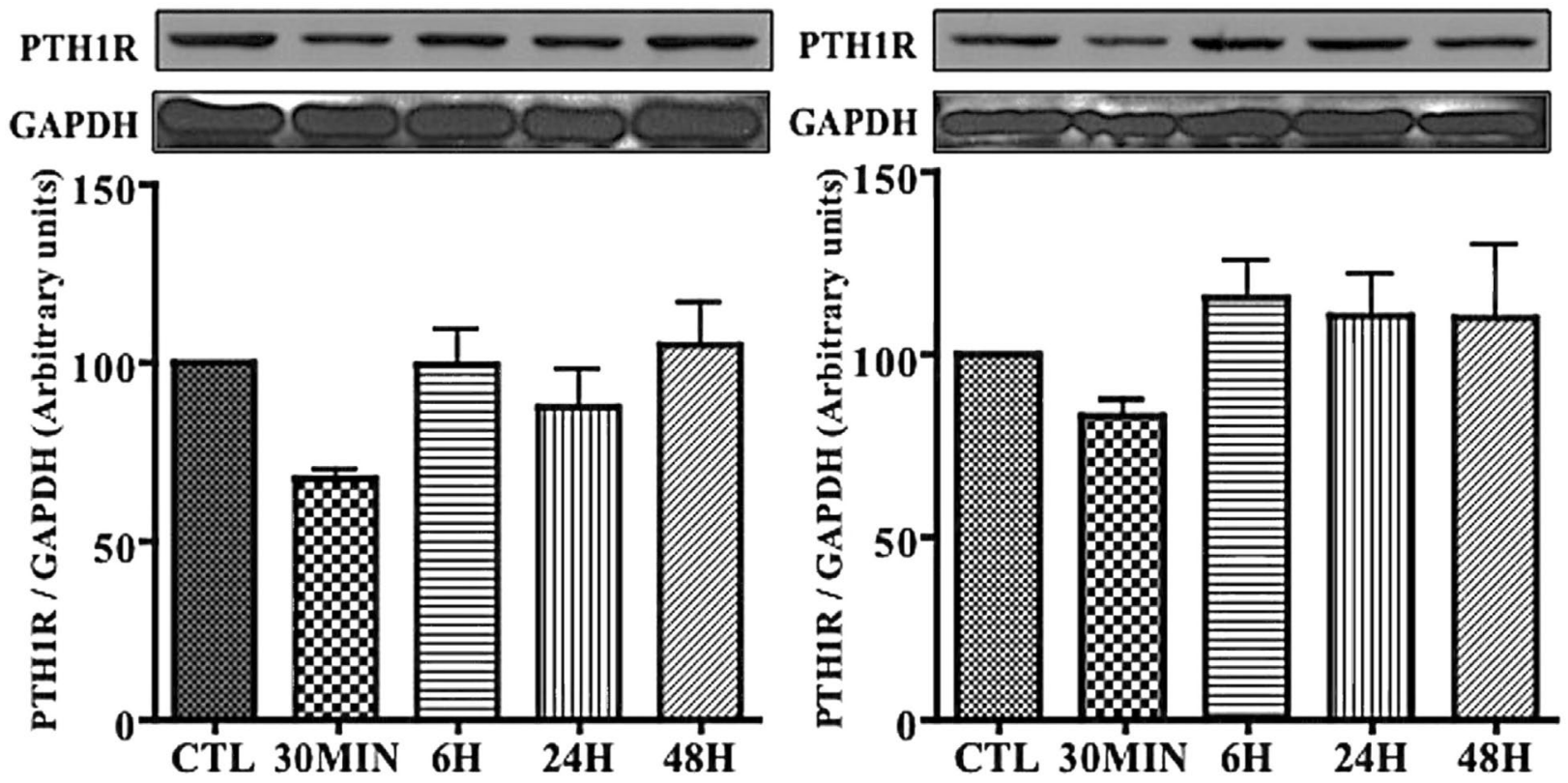

Duration of PTH (100nM) Treatment

Duration of PTH (100nM) Treatment

Fig. 5. Effect of human parathyroid hormone 1-34 (PTH) on parathyroid hormone 1 receptor (PTH1R) expression in annulus fibrosus (AF) and nucleus pulposus (NP) from human intervertebral disc. Protein expression was analysed by immunoblotting using specific antibody to PTH1R. GAPDH was used as a loading control and served to normalise the results. Proteins were resolved on $10 \%$ acrylamide gel and transferred to nitrocellulose membranes. (a) AF and NP tissues from a total of 6 IVDs (L2-L5 of degeneration grades 2 to 5) from 3 donors aged 24, 54 and 68 y were homogenised by mechanical shear and sonication in RIPA buffer to extract the proteins. Two discs each were used for degeneration grades 2 and 4. One disc each was used for degeneration grades 3 and 5. (b) AF and NP cells were cultured for $48 \mathrm{~h}$, supplemented with either $100 \mathrm{nM}$ PTH or without PTH (control). Scans of blots are shown for 1 representative experiment. Quantitative results $(n=3)$ depicting the combined data for 3 separate experiments are presented.

phosphorylation was found to be much higher in NP cells (in the range $779-473 \%$ from $30 \mathrm{~min}$ to $48 \mathrm{~h}$ ) as compared to AF cells (in the range $182-111 \%$ from $30 \mathrm{~min}$ to $48 \mathrm{~h}$ ).

Similarly to Erk1/2, PTHalso led to JNK phosphorylation within 30 min of incubation in both AF (242 $\pm 29 \%$ of control; $p<0.001)$ and NP $(185 \pm 7.8 \%$ of control; $p<0.001)$ cells and remained significantly higher than control up to $6 \mathrm{~h}$. However, the phosphorylation status of JNK declined rapidly after $6 \mathrm{~h}$, reaching basal levels within $24 \mathrm{~h}$ (Fig. 6b).

On the other hand, PTH stimulation of p38 MAPK phosphorylation showed a trend to increase both in AF and NP cells. However, in AF cells increase in p38 MAPK phosphorylation was seen after $30 \mathrm{~min}$ and was significant after $6 \mathrm{~h}$, followed by a decline to control levels. Whereas in NP cells, there was a significant rapid increase in p38
MAPK phosphorylation by $30 \mathrm{~min}$ ( $202 \pm 45 \%$ of control; $p<0.01$ ), followed by decline to below the control levels $(64 \pm 21 \%$ of control; $p<0.05)$ after $24 \mathrm{~h}$ and remained at below basal levels at $48 \mathrm{~h}(53 \pm 32 \%$ of control; $p<0.05)$ of incubation with PTH (Fig. 7a).

PTH had no effect on the total SOX-9 protein content either in AF or in NP cells (Fig. 7b). However, the phosphorylation of SOX-9, in both AF and NP cells, was significantly increased by 30 min (AF cells: $60 \pm 17 \%$; NP cells: $74 \pm 18 \% ; p<0.05)$ and remained high after $1 \mathrm{~h}(\mathrm{AF}$ cells: $118 \pm 26 \%$; NP cells: $161 \pm 20 \%$; $p<0.05$ ).

As stimulation of AF and NP cells by PTH differentially regulated expression of COL II and COL X with concomitant MAPK activation, we further verified if MAPK activation is directly linked with the expressions of collagens. The synthetic compound U0126 reduces 

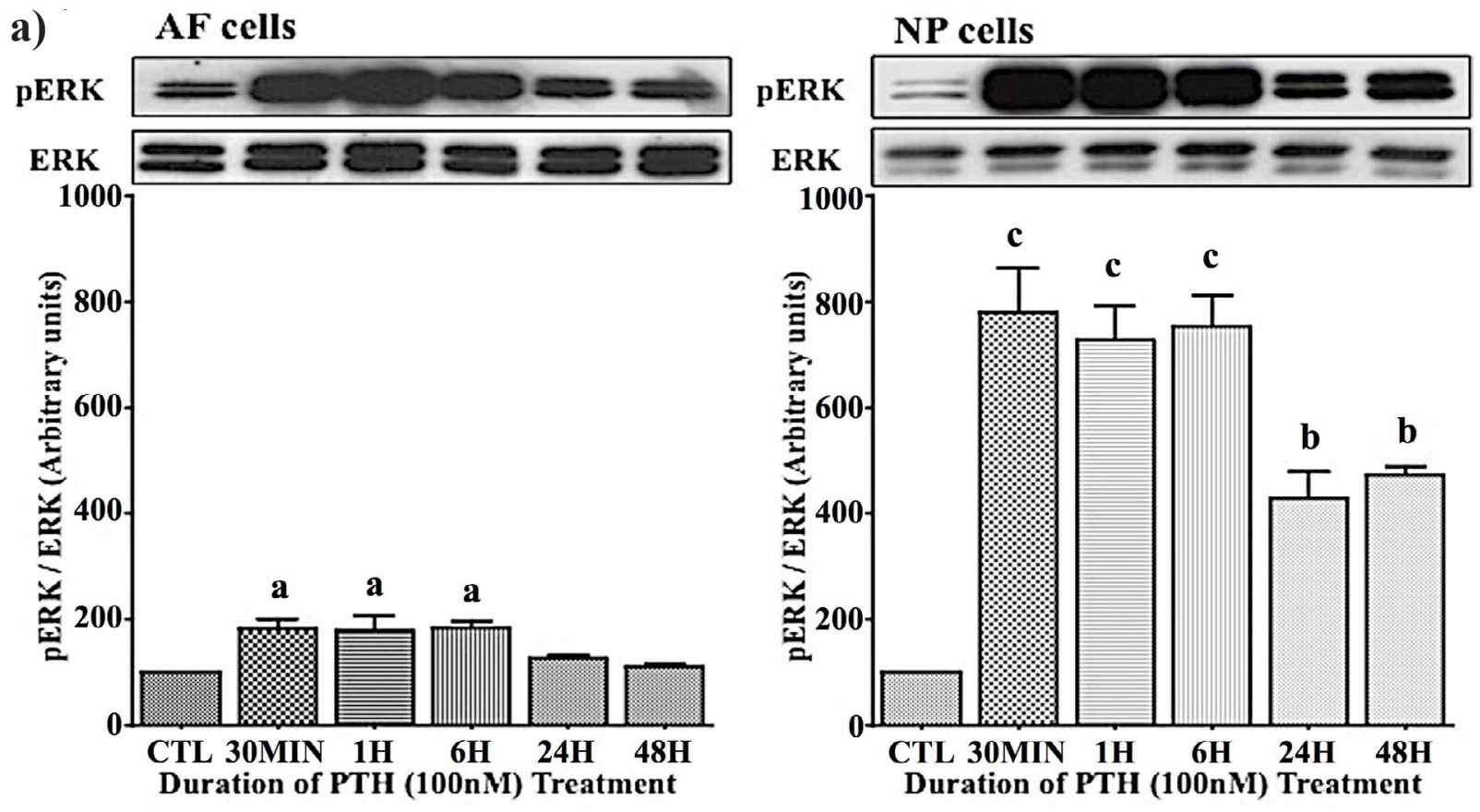

b)

AF cells
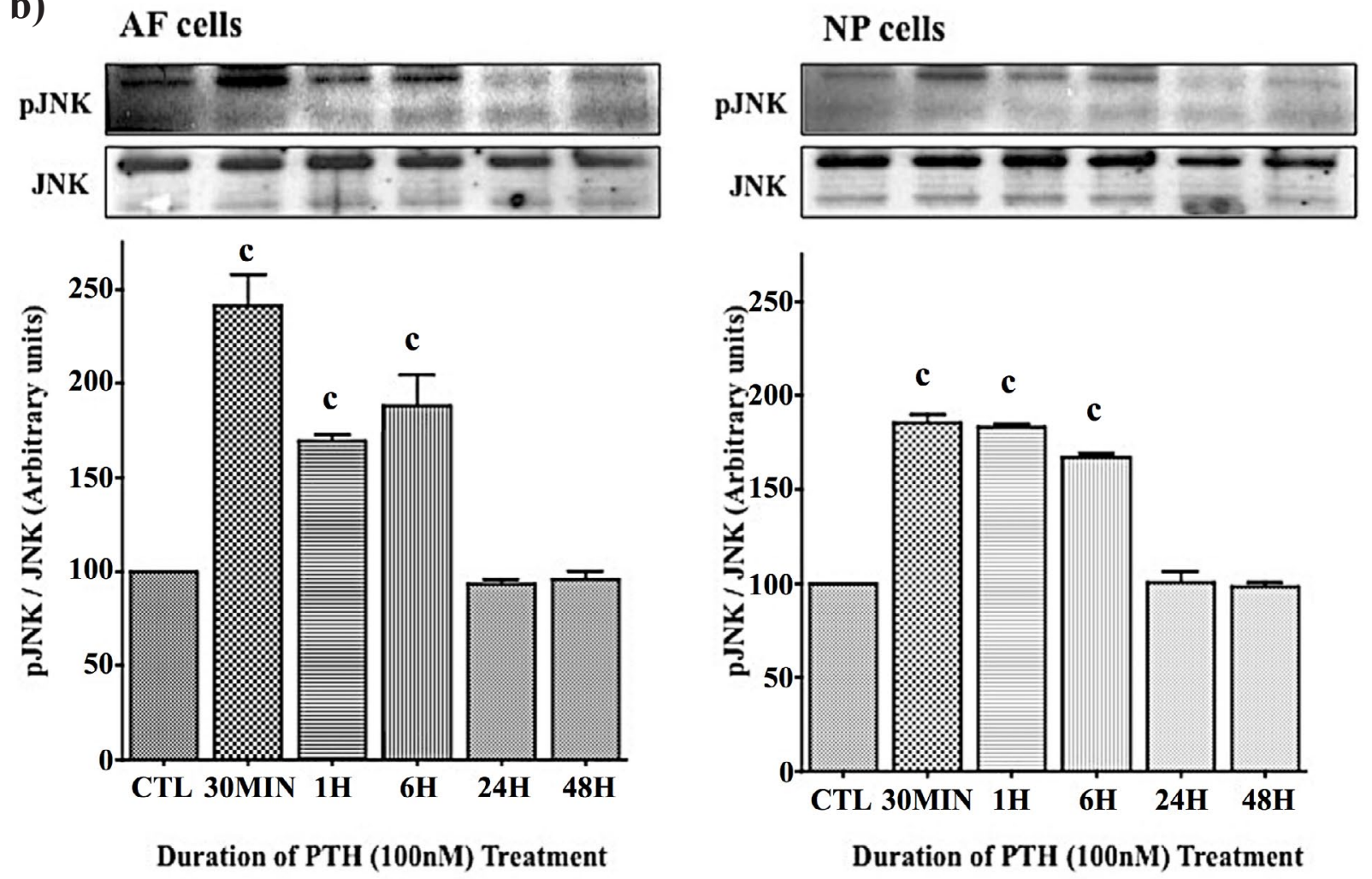

Fig. 6. Human parathyroid hormone 1-34 (PTH) mediated MAPK activation in annulus fibrosus (AF) and nucleus pulposus (NP) cells from human intervertebral disc. AF and NP cells were cultured for $48 \mathrm{~h}$, supplemented with either 100 nM PTH fragment (1-34) or without PTH (CTL). Proteins were resolved on $10 \%$ acrylamide gel and transferred to nitrocellulose membranes. Protein expression was analysed by immunoblotting using specific antibodies against total and phospho-Erk1/2, total and phospho-JNK. Results are mean $\pm \mathrm{SE}\left({ }^{\mathrm{a}} p<0.05 ;{ }^{\mathrm{b}} p<0.01 ;{ }^{\mathrm{c}} p<0.001 v s\right.$. control). Protein bands on gels are shown for 1 representative experiment. Quantitative results depicting the combined data for 3 separate experiments are presented. (a) Total Erk was used to normalise Erk1/2 phosphorylation. (b) Total JNK was used to normalise JNK phosphorylation. 
a)

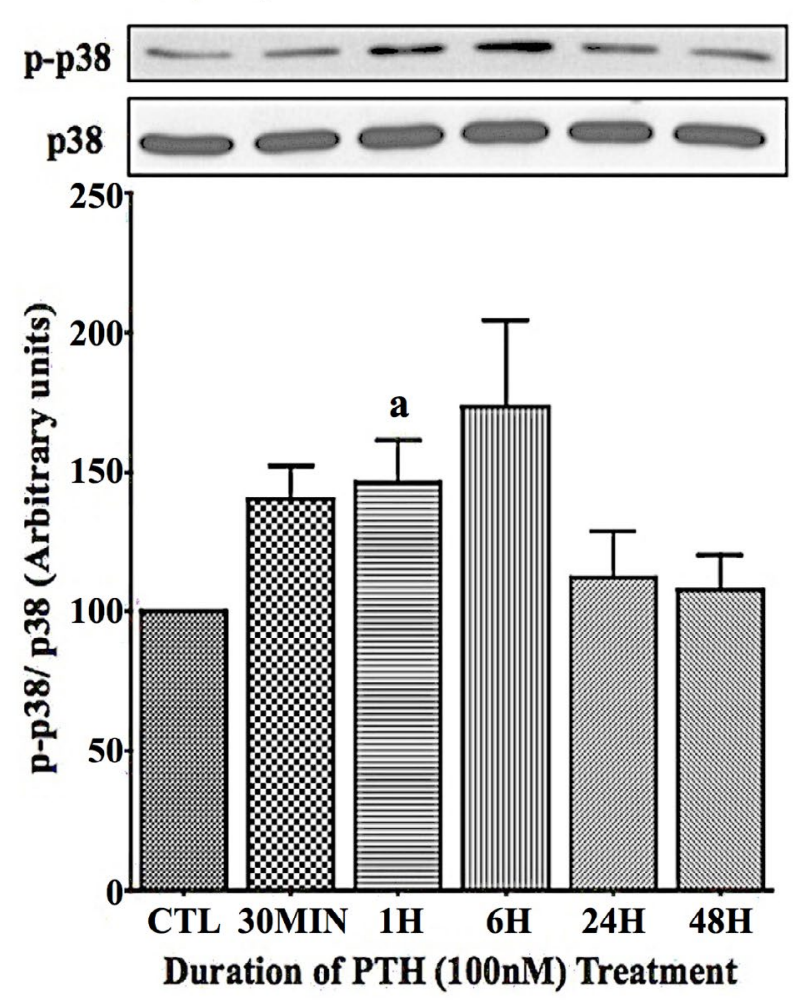

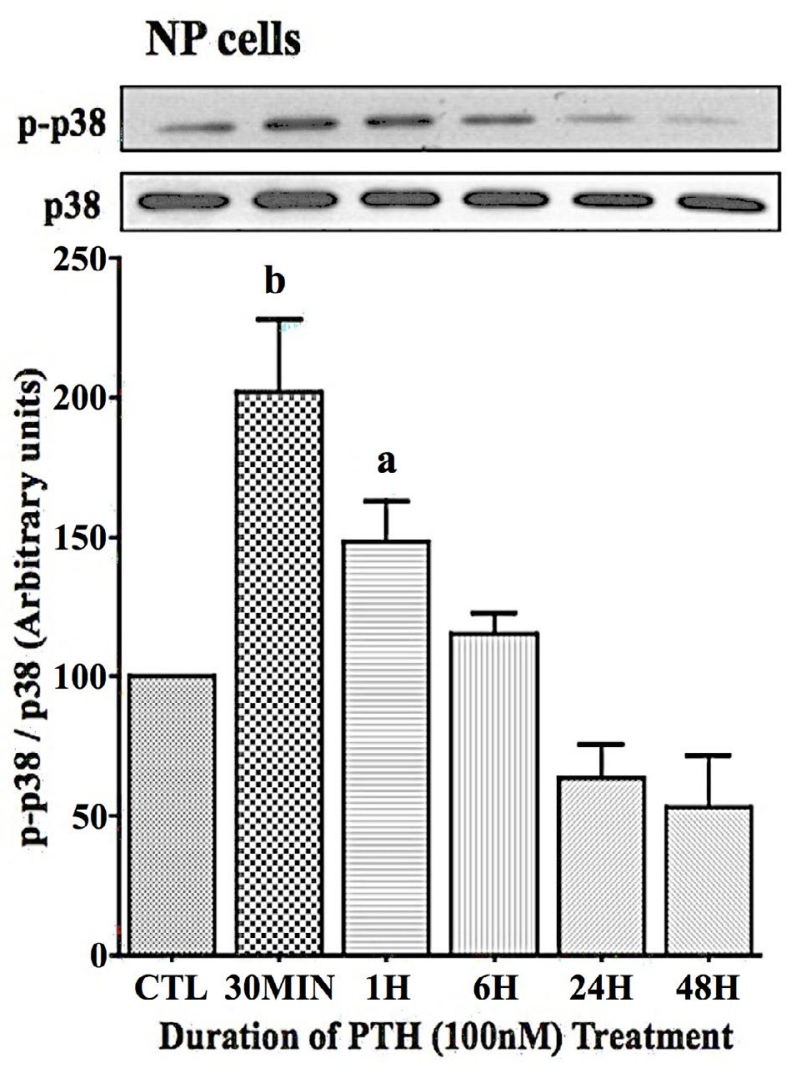

b)

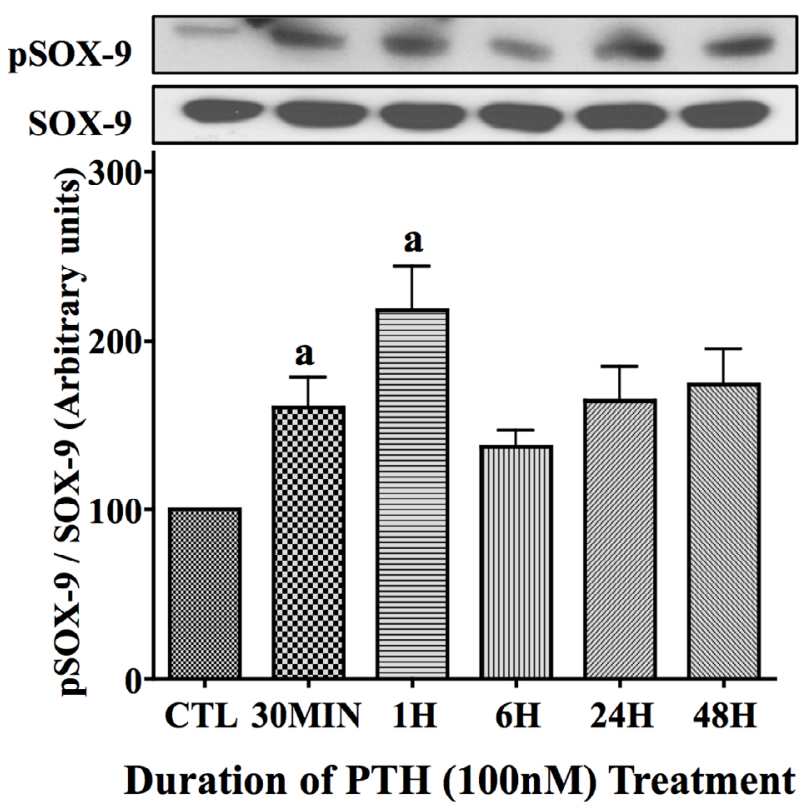

\section{NP cells}

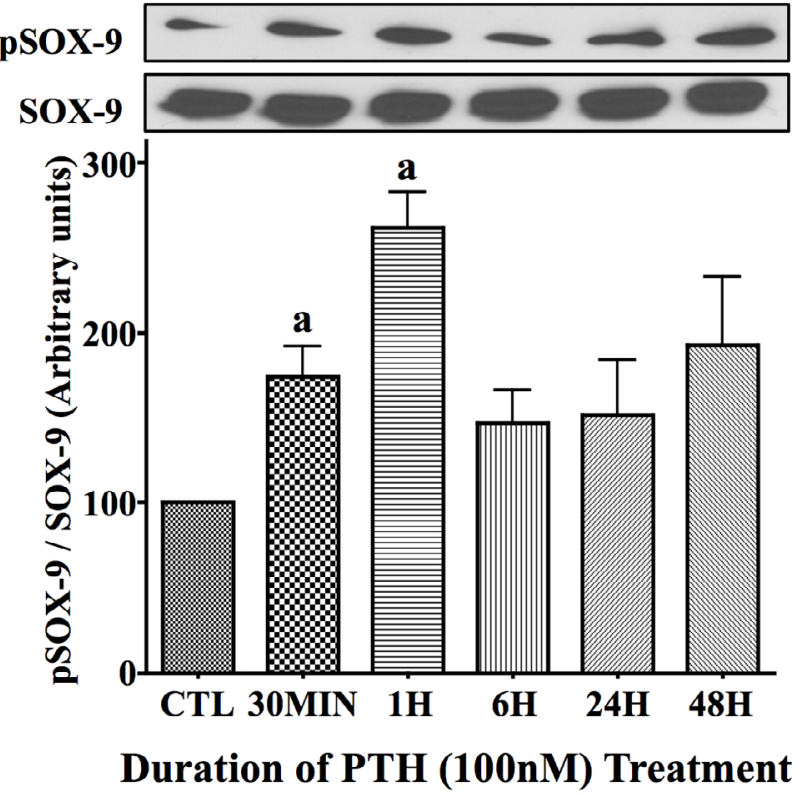

Fig. 7. Human parathyroid hormone 1-34 (PTH) mediated p38 MAPK and SOX-9 activation in annulus fibrosus (AF) and nucleus pulposus (NP) cells from human intervertebral disc. AF and NP cells were cultured for $48 \mathrm{~h}$, supplemented with either $100 \mathrm{nM}$ PTH fragment (1-34) or without PTH (CTL). Proteins were resolved on $10 \%$ acrylamide gel and transferred to nitrocellulose membranes. Protein expression was analysed by immunoblotting using specific antibodies against total and phospho-p38 MAPK and total and phospho-Sox-9. Results are mean \pm SE $\left({ }^{\mathrm{a}} p<0.05 ;{ }^{\mathrm{b}} p<0.01 v s\right.$. control). Protein bands on gels are shown for 1 representative experiment. Quantitative results, depicting the combined data for 3 separate experiments, are presented. (a) Total p38 was used to normalise p38 phosphorylation. (b) Total SOX-9 was used to normalise SOX-9 phosphorylation. 
a) AF cells

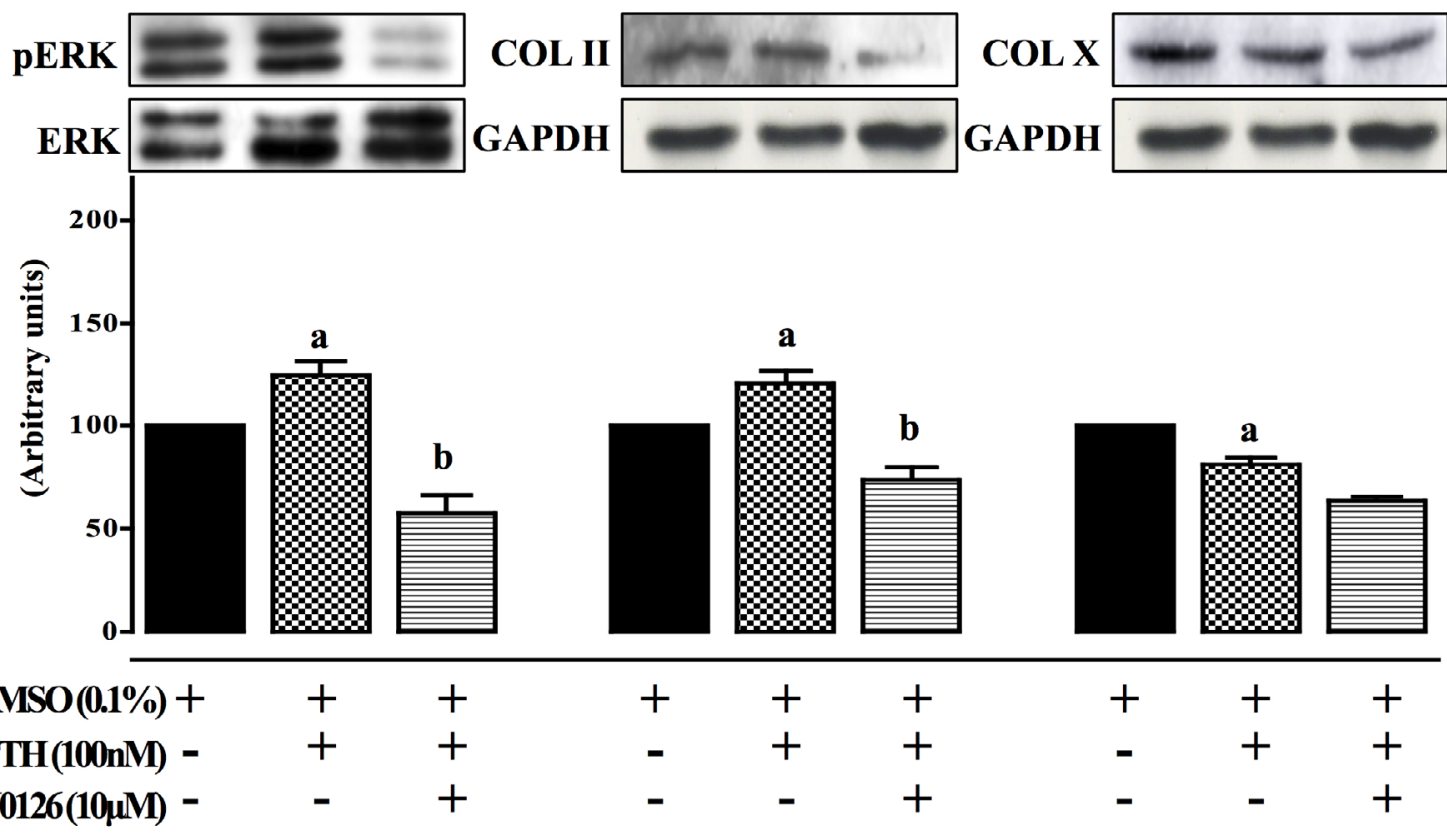

b) NP cells
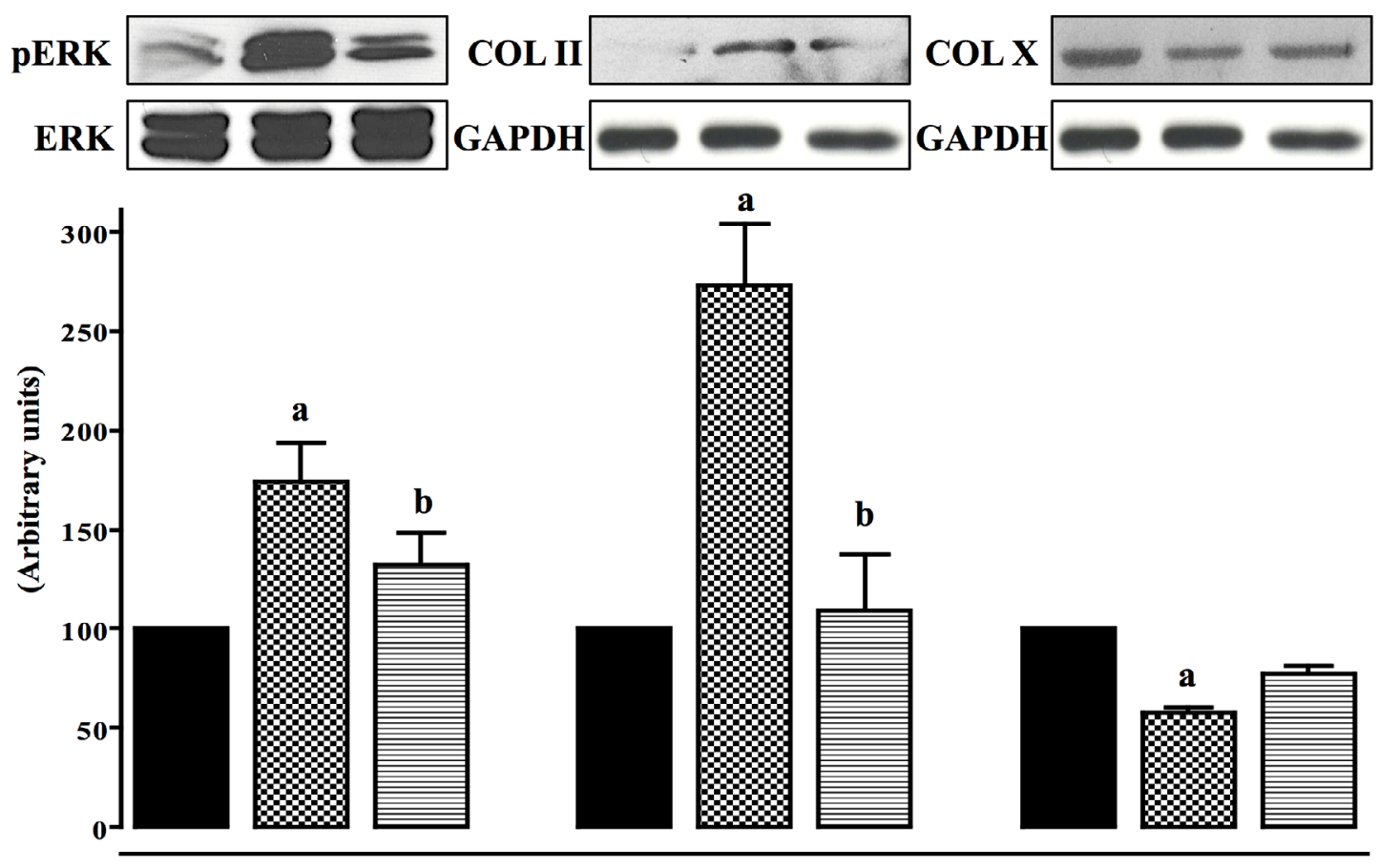

$\begin{array}{lllllllll}\operatorname{DMSO}(0.1 \%)+ & + & + & + & + & + & + & + & + \\ \operatorname{PTH}(100 \mathrm{nM}) & + & + & - & + & + & - & + & + \\ \operatorname{U0126(10\mu M)}- & - & + & - & - & + & - & - & +\end{array}$

Fig. 8. Effect of MEK inhibitor (U0126) on PTH stimulated type II collagen (COL II) and type X collagen (COL X) protein expression in annulus fibrosus (AF) and nucleus pulposus (NP) cells from human intervertebral disc. AF and NP cells were pretreated with U0126 $(10 \mu \mathrm{M})$ in DMSO $(0.1 \%)$ for $30 \mathrm{~min}$ and cultured for $24 \mathrm{~h}$, supplemented with either $100 \mathrm{nM}$ PTH fragment (1-34) or without PTH (0.1\% DMSO control). After the treatments with PTH, cells were harvested and proteins in cell extracts were resolved on $10 \%$ acrylamide gel and transferred to nitrocellulose membranes. Protein expression was analysed by immunoblotting using specific antibodies. GAPDH was used to normalise the results. Results are mean $\pm \mathrm{SE}(n=3)$. (a) ERK phosphorylation and COL II and COL X expression in AF cells ( ${ }^{\mathrm{a}} p<0.05 v s$. control; ${ }^{\mathrm{b}} p<0.01 v s$. PTH). (b) ERK phosphorylation and COL II and COL X expression in NP cells (For pERK, ${ }^{\mathrm{a}} p<0.001 v s$. control; ${ }^{\mathrm{b}} p<0.05$ vs. PTH; For COL II, ${ }^{\mathrm{a}} p<0.001 v s$. control; ${ }^{\mathrm{b}} p<0.001 v s$. PTH; For COL X, ${ }^{\mathrm{a}} p<0.05$ vs. control). 
Fig. 9. Effect of cyclic AMP dependent protein kinase-A inhibitor H-89 dihydrochloride hydrate (H-89 DCH) and forskolin on PTH stimulated type II collagen (COL II) protein expression in annulus fibrosus (AF) and nucleus pulposus (NP) cells from human intervertebral disc. AF and NP cells were pretreated with $\mathrm{H}-89 \mathrm{DCH}(20 \mu \mathrm{M})$ in DMSO $(0.1 \%)$ for $30 \mathrm{~min}$ and cultured for $24 \mathrm{~h}$, supplemented with either $100 \mathrm{nM}$ PTH fragment (1-34) or without PTH $(0.1 \%$ DMSO control). Cells were also cultured for $24 \mathrm{~h}$, supplemented with forskolin $(10 \mu \mathrm{M})$ in DMSO $(0.1 \%)$ alone or with PTH. After incubations, cells were harvested and proteins in cell extracts were resolved on $10 \%$ acrylamide gel and transferred to nitrocellulose membranes. Protein expression was analysed by immunoblotting using specific antibodies. GAPDH was used to normalise data. Results are mean $\pm \mathrm{SE}$ $(n=3)$. (a) COL II expression in AF cells ( ${ }^{\mathrm{a}} p<0.05$ vs. control; ${ }^{\mathrm{b}} p<0.05$ vs. PTH).

(b) COL II expression in NP cells $\left({ }^{\mathrm{b}} p<0.01\right.$ vs. control; ${ }^{c} p<0.001$ vs. PTH). a)
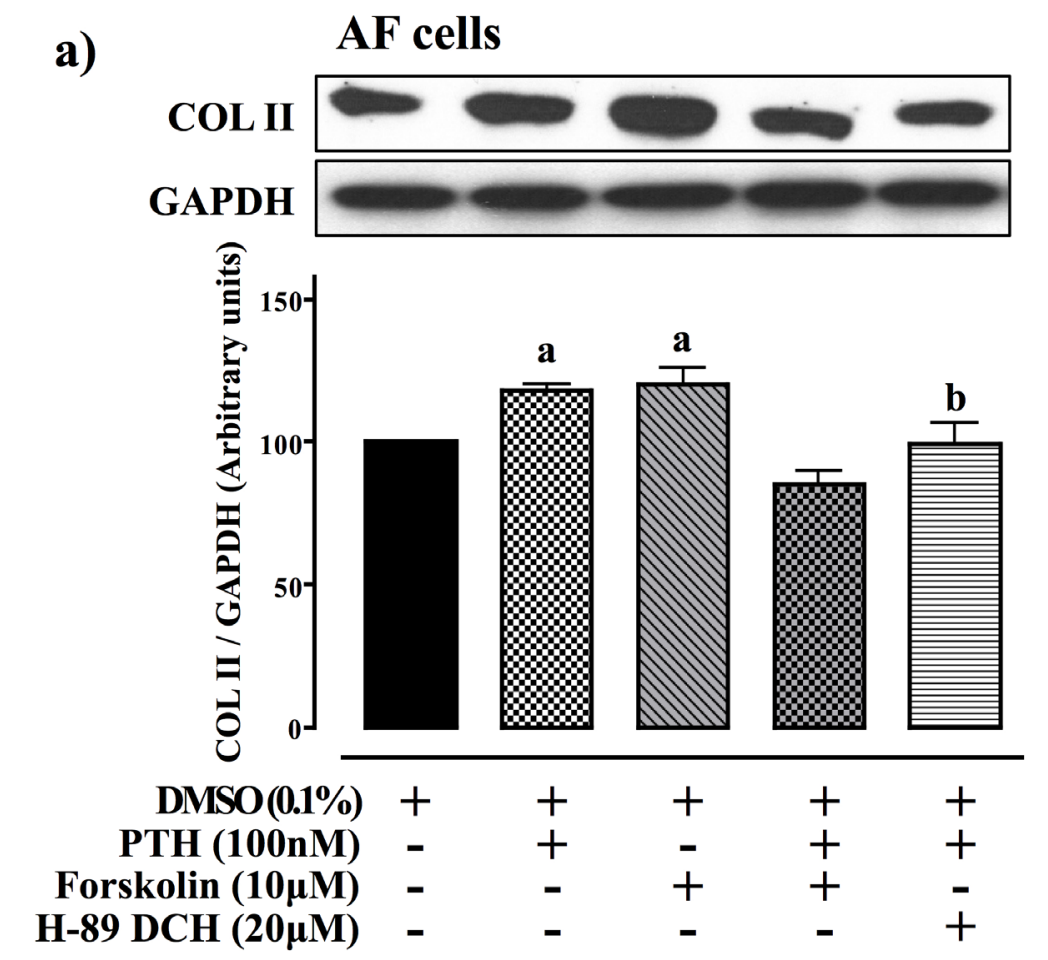

b)

NP cells
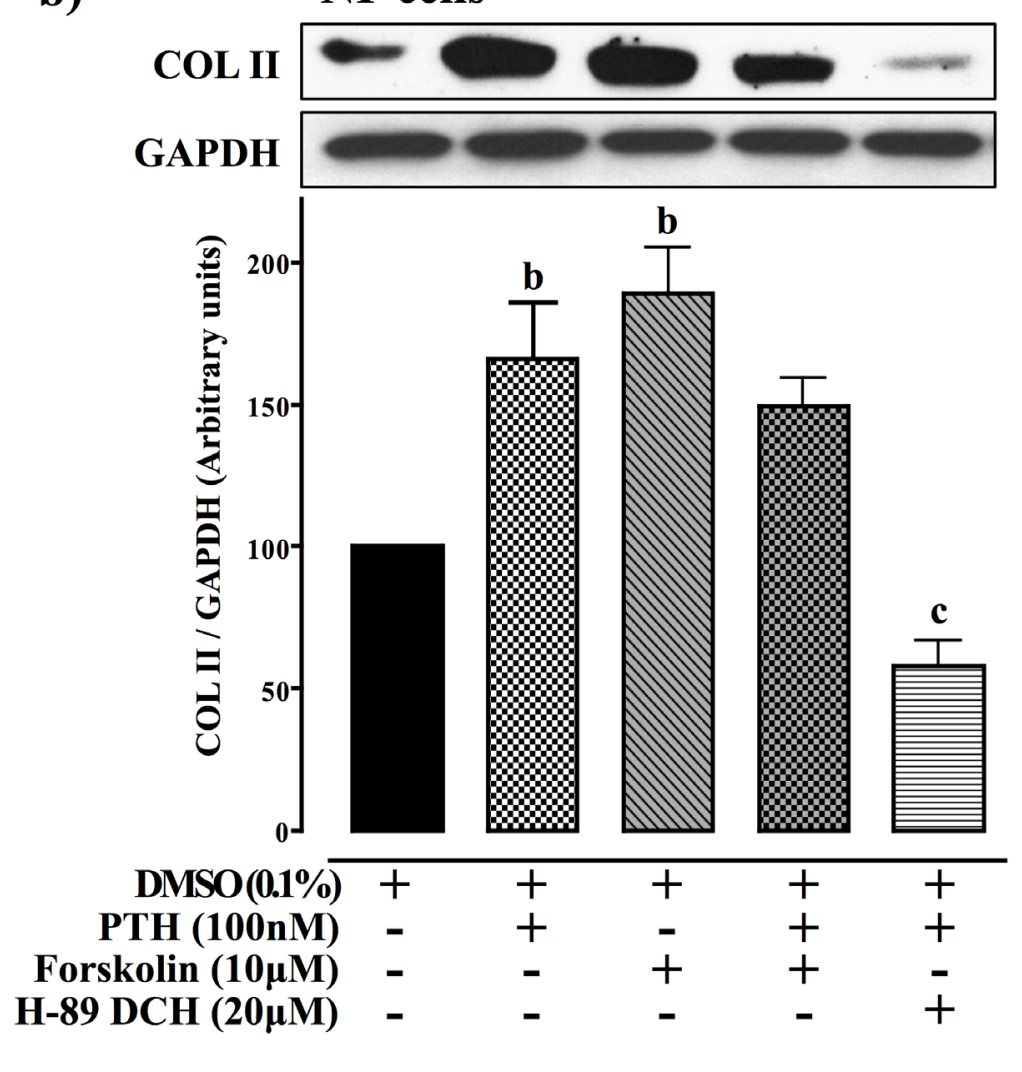

the phosphorylation of MAPK (Erk 1/2) by inhibiting the activity of MAP Kinase (MAPKK or MEK 1/2). Preincubation of AF and NP cells with U0126, prior to the stimulation with $\mathrm{PTH}$, attenuated the expression of COL II in both $\mathrm{AF}$ ( $39 \%$ decrease; $p<0.001$; Fig. 8 a) and NP cells $(60 \%$ decrease; $p<0.001$; Fig. $8 \mathrm{~b})$. Conversely, U0126 had no significant effect on PTH attenuation of COL X expression. However, only in NP cells was COL $\mathrm{X}$ expression partially rescued by MEK inhibitor
U0126 ( 15\%), although the results were not statistically significant (Fig. 8b).

\section{Effect of protein kinase A inhibitor on PTH stimulated COL II expression}

Since PTH is known to exert its cellular effect via both Gaq and Gas signalling, we wanted to examine whether the observed effects of PTH on MAPK signalling and COL II expression are mediated through Gas pathway. 
Treatment of AF and NP cells with forskolin, a known activator of adenylyl cyclase, increased the expression of COL II similar to PTH (Fig. 9). Inhibition of protein kinase A, which is cyclic AMP dependent, by pre-incubation of AF and NP cells with $\mathrm{H}-89$ dihydrochloride hydrate (H-89 $\mathrm{DCH})$, led to significant decrease in PTH stimulated COL II expression (AF cells: $16 \%$ decrease, $p<0.05$; (Fig. 9a); NP cells: $65 \%$ decrease, $p<0.001$; (Fig. 9b)). Combination of forskolin with PTH had no additive/synergistic effect on COL II expression, suggesting a common mechanism between these two stimulators (Fig. 9).

\section{Discussion}

The therapeutic use of PTH, as an anabolic agent in the reversal of osteoporosis, by its intermittent administration, is now well recognised (Lane and Morris, 2005; Thomas, 2006). While the role of PTH on bone homeostasis is well known, not much information on its involvement in the control of disc degeneration is available. Calcification is a pathological process that may lead to impairment of nutrient supply and disc metabolism in degenerative discs (Hristova et al., 2011). Although PTH is known to suppress type $\mathrm{X}$ collagen expression and calcification, while stimulating type II collagen (Harrington et al., 2004; Chang et al., 2009; Mwale et al., 2010), there has been no attempt to supplement PTH to cells of the degenerate human disc in order to inhibit ongoing mineral deposition and stimulate matrix repair. The present study, which investigated the effects of PTH on disc cells from degenerative discs, represented a first step towards the long-term goal of biological repair of the degenerative disc. Since PTH can exert both catabolic and anabolic effects, depending upon its concentration and duration of its administration, we have examined its potential use in countering IVD degeneration and the possible signalling mechanisms involved in this process.

It has been shown that PTH increases the number of mesenchymal stem cells (Ohishi and Schipani, 2011) and exerts anti-apoptotic and pro-differentiating effects on osteoblasts and alters the distribution of type I collagen orientation as part of its action on remodelling (Ascenzi et al., 2012). We recently reported that in mesenchymal stem cells from OA patients, PTH reduces the expression of COL X while enhancing COL II expression (Mwale et al., 2010). The results of the present study demonstrate that PTH up-regulates COL II while downregulating the expression of COL X, in both NP and AF cells. Our results also show that the effect of PTH on COL II expression is at the transcriptional level in both AF and NP cells. PTH also downregulated COL X gene expression in NP cells, which led to the reduction in COL X protein expression.

We previously found the presence of calcium deposits and COL $\mathrm{X}$ and also higher level of the indicators of calcification potential in degenerative discs but not in normal discs (Hristova et al., 2011). The current results showing the ability of PTH to curtail these parameters suggest the importance of PTH in disc repair. Inasmuch as both NP and AF cells are found to express PTH1R, the observed effects of PTH are very likely due to PTH binding and activation of PTH1R on these cells. Interestingly, expression of PTH1R is not significantly altered by treatment with PTH, over $48 \mathrm{~h}$. However, the expression of PTH1R was previously shown to be downregulated by PTHrP in vascular smooth muscle cells (Song et al., 2009) and by PTH in UMR-106 osteoblast like cells (Kawane et al., 2003). These differences between earlier studies and our present observations can be due to different cell types. PTH1R expression is upregulated in degenerated disc tissue, which is probably a feedback mechanism to protect the disc by slowing down further degeneration.

PTH activation of the PTH1R is known to stimulate signalling cascades, in a cell type dependent manner, involving adenylate cyclase/ protein kinase $\mathrm{A}$, phospholipase $\mathrm{C}$ / protein kinase $\mathrm{C}$ and MAPKs, leading to both anabolic and catabolic actions of PTH in bone. Thus, during osteoblast proliferation and differentiation, MAPK signalling was found to increase as well as decrease by PTH (Swarthout et al., 2001). Recent studies showed that the anabolic effects of PTH on osteoblast differentiation are mediated via the rapid downregulation of MAPK phosphorylation, mediated by a specific MAPK phosphatase (Mahalingam et al., 2011). Conversely, the catabolic and mineralisation inhibitory functions of PTH can be mediated via the activation of both PKA and MAPK (Erk1/2) signalling (Suttamanatwong et al., 2007). Thus, in keeping with the potential calcification-inhibitory effect, we found that MAPK signalling is strongly activated by PTH in both types of IVD cells. The PTH effect on Erk1/2 phosphorylation is much stronger and rapid in the NP cells as compared to AF cells. A similar trend was observed with JNK and p38 MAPK phosphorylation. These effects of PTH on MAPK activation precede the effects on COL II and COL X expression. Therefore, we tested the possibility of MAPK signalling being directly responsible for the altered expression of collagens by PTH treatment. The results showed that, an upstream inhibitor of MAPK signalling, U0126, abrogated PTH-mediated regulation of COL II expression both in AF and NP cells. However, with respect to COL X expression, we found such effects only in NP cells. This strongly implicated that at least in NP cells, MAPK signalling is instrumental in the PTH-mediated inverse regulation of COL II and COL X expression. This is in agreement with a recent study (Harrington et al., 2010), showing a rescue of COL X expression by MAPK inhibitors in a model of avian sterna.

Since the effects of PTH can also be mediated via the Gos signalling and PKA pathway, we tested if this pathway is activated in disc cells. The PKA/cAMP pathway is known to be a major player in regulating the synthesis of COL II via the phosphorylation/activation of transcription factor SOX-9 (De Crombrugghe et al., 2001). In the present study, PTH treatment significantly increased SOX-9 phosphorylation and is likely to be involved in upregulation of COL II expression. We then tested if the PKA/cAMP pathway also contributes to the increase in COL II expression by PTH. We found that, both in NP and AF cells, treatment with forskolin alone (an activator of adenylate cyclase (thus the cAMP pathway)) enhances the expression of COL II, while having no effect on COL X (data not illustrated), confirming the importance of cAMP 
pathway in COL II expression. This is in agreement with earlier reports showing that PKA is not involved in PTH mediated reduction in COL $\mathrm{X}$ expression in avian sterna (Harrington et al., 2010). The lack of cumulative effect of forskolin and PTH suggested that these two agents share the same pathway to exert their effects. In further confirmation of the significance of PKA pathway, we noticed that H89 $\mathrm{DCH}$, an inhibitor of PKA, abrogated the PTH stimulation of COL II expression in both NP and AF cells.

An important effect of PTH on bone homeostasis is its inhibitory effect on ALP levels. It has been shown that PTH reduces the expression of ALP in a clonal rat osteosarcoma cell line via a cAMP dependent pathway (Majeska and Rodan, 1982). In agreement with this, we found that in NP cells (whose cAMP pathway appears to respond more robustly than that of the AF cells) PTH treatment caused a time-dependent decrease in ALP activity from $6 \mathrm{~h}$. Considering the promoting role of ALP on mineralisation, the decrease in this enzyme activity is in line with the potential anti-calcification effects of PTH in IVD cells. ALP is known to be an ectoenzyme, generating inorganic phosphate by hydrolysing monophosphate esters, including inorganic pyrophosphate - an inhibitor of mineralisation (Orimo, 2010). The extracellular matrix vesicles are critical for mineralisation by initiating the formation of hydroxyapatite, by elevated concentration of phosphate, contributed by ALP activity and calcium, derived from intracellular sources. PTH action is probably mediated through the activation of the Gaq signalling pathway and via the production of inositol triphosphate, which releases calcium from endoplasmic reticulum. PTH treatment of NP cells selectively increased levels of calcium and its release extracellularly. This probably ensures reduced intracellular calcium levels preventing its possible crystallisation in the NP cells, which has been associated with proinflammatory cytokine release in vascular smooth muscle cells (Ewence et al., 2008). The extracellularly released calcium may not contribute to mineralisation either, due to reduced phosphate availability because of lowered ALP activity by $\mathrm{PTH}$.

Collectively, our present results suggest that $\mathrm{PTH}$, by acting via both MAPK and PKA signalling pathways, helps in retarding IVD degeneration by significantly decreasing calcification in NP as well as AF cells. This potential of PTH is of significant therapeutic value, in preventing IVD degeneration due to calcification. The differential expression of COL II and COL X suggests that PTH may convert hypertrophic disc cells (Rutges et al., 2010) to a pre-hypertrophic phenotype and that the regulation of both COL II and COL X expression may be linked in disc cells. PTH was previously shown to increase proteoglycan and collagen content in growth plate chondrocytes (Ishikawa et al., 1997). PTH therefore has the potential for stimulating not only COL II but also proteoglycan synthesis and suppressing markers of calcification potential in degenerate disc cells.

Finally, it is important to note that while cell-based therapies may achieve cellular repair of the degenerated disc matrix, the environment of the degenerated disc may be unsuitable for the generation of adequate repair. It is known that intense calcification is seen in degenerated discs
(Roberts et al., 1993; Hristova et al., 2011), which may not be favourable for survival of implanted cells. Disturbances in nutrient supply have been shown to affect transport of oxygen and lactic acid into and out of the disc (Urban et $a l ., 2001)$. If this is the case then supplementation of the NP with additional cells may be of immediate benefit but ultimately destined to failure. Supplementation of the degenerated disc with PTH can improve the efficacy of cell therapies by reducing further calcification.

\section{Acknowledgements}

The authors gratefully acknowledge financial support from the Canadian Institutes for Health Research (CIHR).

\section{References}

Adams MA, Roughley PJ (2006) What is intervertebral disc degeneration, and what causes it? Spine (Phila $\mathrm{Pa}$ 1976) 31: 2151-2161.

Antoniou J, Steffen T, Nelson F, Winterbottom N, Hollander AP, Poole RA, Aebi M, Alini M (1996) The human lumbar intervertebral disc: evidence for changes in the biosynthesis and denaturation of the extracellular matrix with growth, maturation, ageing, and degeneration. J Clin Invest 98: 996-1003.

Ascenzi MG, Liao VP, Lee BM, Billi F, Zhou H, Lindsay R, Cosman F, Nieves J, Bilezkian JP, Dempster DW (2012) Parathyroid hormone treatment improves the cortical bone micro-structure by improving the distribution of type I collagen in postmenopausal women with osteoporosis. J Bone Miner Res 27: 702-712.

Babich M, Choi H, Johnson RM, King KL, Alford GE, Nissenson RA (1991) Thrombin and parathyroid hormone mobilize intracellular calcium in rat osteosarcoma cells by distinct pathways. Endocrinology 129: 1463-1470.

Bibby SR, Meir A, Fairbank JC, Urban JP (2002) Cell viability and the physical environment in the scoliotic intervertebral disc. Stud Health Technol Inform 91: 419421.

Bogduk N (1991) The lumbar disc and low back pain. Neurosurg Clin N Am 2: 791-806.

Boos N, Nerlich AG, Wiest I, von der Mark K, Aebi M (1997) Immunolocalization of type X collagen in human lumbar intervertebral discs during ageing and degeneration. Histochem Cell Biol 108: 471-480.

Boos N, Weissbach S, Rohrbach H, Weiler C, Spratt KF, Nerlich AG (2002) Classification of age-related changes in lumbar intervertebral discs: 2002 Volvo Award in basic science. Spine (Phila Pa 1976) 27: 2631-2644.

Buckwalter JA (1995) Aging and degeneration of the human intervertebral disc. Spine (Phila Pa 1976) 20: $1307-$ 1314.

Caporale A, Gesiot L, Sturlese M, Wittelsberger A, Mammi S, Peggion E (2012) Design, conformational studies and analysis of structure-function relationships of PTH (1-11) analogues: the essential role of Val in position 2. Amino Acids 43: 207-218. 
Chang JK, Chang LH, Hung SH, Wu SC, Lee HY, Lin YS, Chen CH, Fu YC, Wang GJ, Ho ML (2009) Parathyroid hormone 1-34 inhibits terminal differentiation of human articular chondrocytes and osteoarthritis progression in rats. Arthritis Rheum 60: 3049-3060.

Chelberg MK, Banks GM, Geiger DF, Oegema TR Jr (1995) Identification of heterogeneous cell populations in normal human intervertebral disc. J Anat 186: 43-53.

Civitelli R, Reid IR, Westbrook S, Avioli LV, Hruska KA (1988) PTH elevates inositol polyphosphates and diacylglycerol in a rat osteoblast-like cell line. Am J Physiol 255: E660-667.

De Crombrugghe B, Lefebvre V, Nakashima K (2001) Regulatory mechanisms in the pathways of cartilage and bone formation. Curr Opin Cell Biol 13: 721-727.

Dempster DW, Cosman F, Parisien M, Shen V, Lindsay R (1993) Anabolic actions of parathyroid hormone on bone. Endocr Rev 14: 690-709.

Dobnig H, Turner RT (1995) Evidence that intermittent treatment with parathyroid hormone increases bone formation in adult rats by activation of bone lining cells. Endocrinology 136: 3632-3638.

Ewence AE, Bootman M, Roderick HL, Skepper JN, McCarthy G, Epple M, Neumann M, Shanahan CM, Proudfoot D (2008) Calcium phosphate crystals induce cell death in human vascular smooth muscle cells: a potential mechanism in atherosclerotic plaque destabilization. Circ Res 103: e28-34.

Freemont AJ (2009) The cellular pathobiology of the degenerate intervertebral disc and discogenic back pain. Rheumatology (Oxford) 48: 5-10.

Gruber HE, Hanley EN Jr (1998) Analysis of aging and degeneration of the human intervertebral disc. Comparison of surgical specimens with normal controls. Spine (Phila Pa 1976) 23: 751-757.

Harrington EK, Lunsford LE, Svoboda KK (2004) Chondrocyte terminal differentiation, apoptosis, and type $\mathrm{X}$ collagen expression are downregulated by parathyroid hormone. Anat Rec (Hoboken) 281:1286-1295.

Harrington EK, Coon DJ, Kern MF, Svoboda KK (2010) PTH stimulated growth and decreased Col-X deposition are phosphotidylinositol-3,4,5 triphosphate kinase and mitogen activating protein kinase dependent in avian sterna. Anat Rec (Hoboken) 293: 225-234.

Hayes AJ, Benjamin M, Ralphs JR (2001) Extracellular matrix in development of the intervertebral disc. Matrix Biol 20: 107-121.

Hristova GI, Jarzem P, Ouellet JA, Roughley PJ, Epure LM, Antoniou J, Mwale F (2011) Calcification in human intervertebral disc degeneration and scoliosis. J Orthop Res 29: 1888-1895.

Ishikawa Y, Wu LN, Genge BR, Mwale F, Wuthier RE (1997) Effects of calcitonin and parathyroid hormone on calcification of primary cultures of chicken growth plate chondrocytes. J Bone Miner Res 12: 356-366.

Kawane T, Mimura J, Yanagawa T, Fujii-Kuriyama Y, Horiuchi N (2003) Parathyroid hormone (PTH) down-regulates $\mathrm{PTH} / \mathrm{PTH}$-related protein receptor gene expression in UMR-106 osteoblast-like cells via a 3',5'-cyclic adenosine monophosphate-dependent, protein kinase A-independent pathway. J Endocrinol 178: 247-256.
Lane N, Morris S (2005) New perspectives on parathyroid hormone therapy. Curr Opin Rheumatol 17:467-474.

Lefebvre V, Behringer RR, de Crombrugghe B (2001) L-Sox5, Sox6 and Sox9 control essential steps of the chondrocyte differentiation pathway. Osteoarthritis Cartilage 9 Suppl A: S69-75.

Loreto C, Musumeci G, Castorina A, Martinez G (2011) Degenerative disc disease of herniated intervertebral discs is associated with extracellular matrix remodeling, vimentin-positive cells and cell death. Ann Anat 193: 156162.

Mahalingam CD, Datta T, Patil RV, Kreider J, Bonfil RD, Kirkwood KL, Goldstein SA, Abou-Samra AB, Datta NS (2011) Mitogen-activated protein kinase phosphatase 1 regulates bone mass, osteoblast gene expression, and responsiveness to parathyroid hormone. J Endocrinol 211: 145-156.

Majeska RJ, Rodan GA (1982) Alkaline phosphatase inhibition by parathyroid hormone and isoproterenol in a clonal rat osteosarcoma cell line. Possible mediation by cyclic AMP. Calcif Tissue Int 34: 59-66.

Mwale F, Yao G, Ouellet JA, Petit A, Antoniou J (2010) Effect of parathyroid hormone on type X and type II collagen expression in mesenchymal stem cells from osteoarthritic patients. Tissue Eng Part A 16: 3449-3455.

Oegema TR Jr (1993) Biochemistry of the intervertebral disc. Clin Sports Med 12: 419-439.

Ohishi M, Schipani E (2011) PTH and stem cells. J Endocrinol Invest 34: 552-556.

Orimo H (2010) The mechanism of mineralization and the role of alkaline phosphatase in health and disease. $\mathrm{J}$ Nihon Med Sch 77: 4-12.

Partridge NC, Bloch SR, Pearman AT (1994) Signal transduction pathways mediating parathyroid hormone regulation of osteoblastic gene expression. J Cell Biochem 55: 321-327.

Reid IR, Civitelli R, Halstead LR, Avioli LV, Hruska KA (1987) Parathyroid hormone acutely elevates intracellular calcium in osteoblastlike cells. Am J Physiol 253: E45-51.

Roberts S, Menage J, Eisenstein SM (1993) The cartilage end-plate and intervertebral disc in scoliosis: calcification and other sequelae. J Orthop Res 11: 747-757.

Rutges JP, Duit RA, Kummer JA, Oner FC, van Rijen $\mathrm{MH}$, Verbout AJ, Castelein RM, Dhert WJ, Creemers LB (2010) Hypertrophic differentiation and calcification during intervertebral disc degeneration. Osteoarthritis Cartilage 18:1487-1495.

Schiller PC, D'Ippolito G, Roos BA, Howard GA (1999) Anabolic or catabolic responses of MC3T3-E1 osteoblastic cells to parathyroid hormone depend on time and duration of treatment. J Bone Miner Res 14: 15041512.

Song GJ, Fiaschi-Taesch N, Bisello A (2009) Endogenous parathyroid hormone-related protein regulates the expression of PTH type 1 receptor and proliferation of vascular smooth muscle cells. Mol Endocrinol 23: 16811690.

Suttamanatwong S, Franceschi RT, Carlson AE, Gopalakrishnan R (2007) Regulation of matrix Gla protein by parathyroid hormone in MC3T3-E1 osteoblast-like cells 
involves protein kinase A and extracellular signal-regulated kinase pathways. J Cell Biochem 102: 496-505.

Swarthout JT, Doggett TA, Lemker JL, Partridge NC (2001) Stimulation of extracellular signal-regulated kinases and proliferation in rat osteoblastic cells by parathyroid hormone is protein kinase C-dependent. J Biol Chem 276: 7586-7592.

Swarthout JT, D’Alonzo RC, Selvamurugan N, Partridge NC (2002) Parathyroid hormone-dependent signaling pathways regulating genes in bone cells. Gene 282: 1-17.

Thomas T (2006) Intermittent parathyroid hormone therapy to increase bone formation. Joint Bone Spine 73: 262-269.

Thompson JP, Pearce RH, Schechter MT, Adams ME, Tsang IK, Bishop PB (1990) Preliminary evaluation of a scheme for grading the gross morphology of the human intervertebral disc. Spine (Phila Pa 1976) 15: 411-415.

Urban MR, Fairbank JC, Etherington PJ, Loh FL, Winlove CP, Urban JP (2001) Electrochemical measurement of transport into scoliotic intervertebral discs ex vivo using nitrous oxide as a tracer. Spine (Phila Pa 1976) 26: 984-990.

Vilardaga JP, Bunemann M, Krasel C, Castro M, Lohse MJ (2003) Measurement of the millisecond activation switch of $\mathrm{G}$ protein-coupled receptors in living cells. Nat Biotechnol 21: 807-812.

\section{Discussion with Reviewers}

Reviewer I: How would you envisage applying PTH clinically?

Authors: We envisage using PTH to resorb mineral, as it may be a viable therapeutic option for improving the nutritional status of degenerated discs during cell implantation therapy. Improved nutrition may lead to better survival of the implanted cells especially when needed to overcome the paucity of cells in a degenerating disc.

Reviewer II: What proof is out there that any calcification occurring inside the disc - so not in the subchondral bone plate - is generalised rather than focal, therefore would this process really affect the course of degeneration?

Authors: There is a lot of proof in the literature showing that initial events may be focal but the overall degenerative process can become generalised. Endplate calcification is implicated in the progression of disc degeneration by decreasing disc nutrition. Calcification can first occur at the edges of the cells and subsequently spread around the whole cell and beyond into the matrix. Even in naturally occurring ovine model of human disc degeneration, calcification can be diffuse. We recently showed generalised calcification not only in human endplates but also in the whole disc. Several studies have shown that this calcification process can really affect the course of degeneration. 